\author{
Agata GAJDEK \\ Uniwersytet Rzeszowski \\ agajdek@ur.edu.pl

\section{Dominik PORCZYŃSKI} \\ Uniwersytet Rzeszowski \\ dporczynski@ur.edu.pl
}

\title{
TRWANIE GRANIC ROZBIOROWYCH W PRAKTYKACH, KOLEKCJACH I KRAJOBRAZIE
}

\author{
W POSZUKIWANIU PUNKTÓW STYCZNYCH SOCJOLOGII, \\ MUZEOLOGII I ARCHITEKTURY KRAJOBRAZU
}

ABSTRACT The Ongoing Existence of Partition Borders in Practices, Collections and Landscape. In Search of Common Points of Sociology, Museology and Landscape Architecture

The subject of this paper is the phenomenon of the so called phantom borders former political borders, presently non-existing, however influencing the social environment. Concentrating on practices, collections and landscape we attempt to integrate three disciplines: sociology, museology and landscape architecture to study today's manifestations of these boundaries separating the territories of Poland for 123 years. Recognizing the perspective of borderscaping we assume (phantom) borders as complex and multilevel phenomena thus requiring holistic approach reflected in the application of aforementioned disciplines during intensive ethnographic studies of former Kingdom of Poland and Kingdom of Galicia borderland communities. We argue that successful integration of methods can be based on the assumption of materiality as a common element of interactions, collections and space, making possible - in the second step - a study of meanings invoked by these tangible components and then a recreation of material-symbolic systems shaping everyday life and festive times of phantom-borderlands communities. 
Key words: phantom border, borderscaping, collective identity, collection, cultural landscape

Słowa kluczowe: granica fantomowa, granic obrazowanie, tożsamość zbiorowa, kolekcja, krajobraz kulturowy

- Podobno pan, panie wójcie, idzie do miasta? [do Sandomierza] - A do Polski? Idę. Pan wraca do domu?

Poderwato mię.

- Dokad pan idzie? Do Polski?

- No tak - odpowiada wójt.

- A gdzieżpan do cholery jest?

Wciażjeszcze w przestawnej Austrii?

\section{WPROWADZENIE}

Zamiarem artykułu jest odpowiedź na pytanie, jak granice rozbiorowe przejawiają się we współczesnych praktykach, kolekcjach i krajobrazie. Jest to zadanie mające cel konceptualny i metodologiczny. Poprzez usytuowanie naszych rozważań w określonych ramach teoretycznych i odniesienie się do praktyk, miejsc i przedmiotów, pragniemy zobrazować punkt wyjścia interdyscyplinarnych badań empirycznych. Charakteryzując w ten sposób obszar dociekań, definiujemy problem ontologiczny, który po bliższym przyjrzeniu się zmusza do równoczesnego skonstruowania pytania dotyczącego tego, jakimi metodami badać owo przejawianie się dawnych granic w zjawiskach współczesnych oraz jak można zintegrować trzy różne dyscypliny: socjologię, muzeologię i architekturę krajobrazu wokół badania tego zagadnienia. Aby rozwiązać oba problemy, należy wpierw zdefiniować, czym właściwie są owe granice, czy uzasadniona jest dyskusja o nich z innej niż historyczna perspektywy, a także scharakteryzować kompleks zjawisk, które te granice konstytuują.

Specyfika przedmiotu badań skłania nas do poszukiwania inspiracji i narzędzi dla rozwiązania postawionych problemów w obrębie różnych tradycji i dyscyplin naukowych. Z jednej strony jest tu bowiem mowa o historycznych granicach, współcześnie nieistniejących w sensie politycznym. Można zatem zakładać, że pomocna będzie tradycja badań pogranicza i idące za tym przekonanie o specyficznych układach społeczno-kulturowych generowanych wskutek długotrwałego oddziaływania na siebie różnych centrów politycznych. Należy się przy tym najpierw uporać z pytaniem dotyczącym oddziaływania dawnych granic na przyległe do nich terytoria i zamieszkujące je obecnie społeczności.

1 R. Koseła, Sandomierskie strony, Warszawa 1939, s. 57. 
Relacje z dwudziestolecia międzywojennego pochodzące z obszarów dawnego pogranicza Galicji i Królestwa Polskiego wskazują na wykorzystywanie w tamtym okresie wydarzeń przeszłych do tworzenia stereotypów i nadawania etykiet osobom pochodzącym z drugiej strony granicy². Stąd nazywanie przez mieszkańców okolic Sandomierza osób z południa "galicyjokami”, „rzezakami”, zaś zamieszkujących tereny leżące na lewo od Wisły przez Galicjan: „Moskalami” lub „teperami”. Cytowany we wstępie Roman Koseła wskazuje na stereotypowe postrzeganie przestrzeni geograficznej $\mathrm{i}$ jest to jedna $\mathrm{z}$ wielu utrzymanych $\mathrm{w}$ podobnym tonie anegdot ilustrujących podziały istniejące w różnych wymiarach społecznych okolic międzywojennego Sandomierza. Zauważalne są tutaj najbardziej podstawowe z perspektywy antropologicznej ${ }^{4}$ lub socjologicznej ${ }^{5}$ procesy tworzenia stereotypów, wykorzystywane dla porządkowania rzeczywistości, budowania tożsamości zbiorowej i odróżniania się od „innych”. Warte zastanowienia jest wykorzystywanie - pomimo kilkunastoletniego wtedy funkcjonowania w obrębie jednego organizmu państwowego - opresyjnego dziedzictwa do tworzenia etykiet i odnoszenia się wyłącznie do negatywnych cech danych zbiorowości dla tworzenia ich charakterystyk.

Opowieść Koseły może oczywiście zostać zakwestionowana jako uzasadniony punkt wyjścia do budowania narracji wokół wpływu granic rozbiorowych na obecne relacje społeczne, ponieważ dotyczy okresu względnie mało odległego w czasie od daty scalenia trzech dzielnic w drugą Rzeczpospolitą. Nasze rozmowy z mieszkańcami tego obszaru wskazują jednak na inne - współcześnie używane - pojęcia. Tarnobrzeżanie nazywają mieszkańców drugiej strony Wisły „parasolami”, zaś ci ostatni używają terminu „żółtobrzuchy” na oznaczenie obywateli dawnej Galicjí6. Podział potwierdzają również prace Jerzego Bartkowskiego. Wyniki prowadzonych przezeń badań wskazują istotny wpływ dziedzictwa rozbiorowego na zachowania społeczne ${ }^{7}$. Wyjaśnienia tego fenomenu można się doszukiwać w kategoriach długiego trwania ${ }^{8}$, które strukturyzuje najważniejsze, z punktu widzenia analiz historycznych i makrostrukturalnych, przemiany gospodarcze, cywilizacyjne i religijne sprzyjające utrwaleniu zjawisk kulturowych? Według Immanuela Wallersteina konieczne jest badanie zachodzących w tych

\section{Tami்e, s. 56.}

3 Od „rzezi galicyjskiej”.

4 A. Cohen, Symbolic Construction of Community, London 1985, s. 74.

5 G. Simmel, Obcy, [w:] tegoż, Most i drzwi, przeł. M. Łukasiewicz, Warszawa 2006.

6 Trudno wskazać genezę tych przezwisk. Jedno z wytłumaczeń jest takie, że mieszkańcy Sandomierza, spacerując nadwiślańskimi bulwarami, używali parasoli przy słonecznej pogodzie, co było kuriozalne dla ubogich Galicjan. „Żółtobrzuchy” z kolei mają pochodzić od żółtych wyłogów mundurów jednostek patrolujących granicę.

J. Bartkowski, Tradycja zaborów a wspótczesne zachowania spoteczne w Polsce, [w:] Oblicza lokalności. Tradycja i wspótczesność, red. J. Kurczewska, Warszawa 2004, s. 267.

8 Tamże, s. 422.

9 I. Wallerstein, Time and Duration: The Unexcluded Middle, or Reflections on Braudel and Prigogine, „Thesis Eleven” 1998, vol. 54, nr 1, s. 79-87. 
ramach cyklów ${ }^{10}$, a za koniec jednego z nich można przyjąć upadek trzech monarchii. Trwanie granic rozbiorowych można uznać za przedłużający się czas jego wygaszania lub za element zespolony już z „ramą” długiego trwania.

Galicyjska bieda, a z drugiej strony autonomia, przejawiająca się w możliwości prowadzenia działalności kulturalnej i istnieniu autentycznego samorządu, pozwoliły wytworzyć odrębny system kulturowy i jednocześnie, dzięki niskiej mobilności mieszkańców - utrwalić go ${ }^{11}$. Galicja funkcjonuje nadal jako mit, „raj utracony” ${ }^{12}$ w pamięci społecznej, literaturze i praktykach społecznych, a poprzez nie trwają i oddziałują nadal jej dawne granice ${ }^{13}$.

W naukach społecznych funkcjonuje od pewnego czasu pojęcie granicy fantomowej, którą definiuje się jako dawniej istniejące granice polityczne, obecnie nieistniejące fizycznie, lecz nadające strukturę przestrzeni współczesnej i przejawiające się w świadomości i praktykach społecznych ${ }^{14}$. Analizując mapy polityczne Europy Środkowej odnoszące się do różnych okresów historycznych, można jednoznacznie stwierdzić, że terytoria współcześnie istniejących państw są poprzecinane siecią nakładających się na siebie dawnych granic, oddzielających zakończone z różnych przyczyn lub wciąż kontynuowane projekty polityczne. Popularnym elementem dyskursu publicznego jest wskazywanie podziału Polski na zachodnią Polskę A i wschodnią Polskę B, które to rozróżnienie wspierają wyniki wyborów. Pomorze, Wielkopolska i Śląsk, do 1918 r. będące terytorium Cesarstwa Niemieckiego, głosują częściej na partie i kandydatów liberalnych, zaś ściana wschodnia i dawna Galicja na konserwatywnych ${ }^{15}$. Analogiczne zjawiska zachodzą w Czechach ${ }^{16}$ i na Ukrainie ${ }^{17}$. Zatem z perspektywy makrostrukturalnej, wyrażonej w statystykach, istnieje obecnie związek między dawnymi dzielnicami a preferencjami i praktykami politycznymi. W tym miejscu jednak pojawia się pytanie, czy zjawiska te znajdują odzwierciedlenie na niższych poziomach analizy socjologicznej i w życiu codziennym członków społeczności lokalnych zamieszkujących obszary pograniczy fantomowych.

10 I. Wallerstein, World-System Analysis. An Introduction, Durham 2006, s. 15.

11 Tamże.

12 J. Wierzejska, Idea Galicji po(st)granicznej w ukrainskim i polskim dyskursie postkolonialnym. Na przyktadzie eseistyki Jurija Andruchowycza i Andrzeja Stasiuka, „Teksty Drugie” 2014, nr 6, s. 283-304. T. Borejza, Mit Galicji, „Przegląd” 2015, vol. 792, nr 10, s. 25-26.

13 T. Borejza, Mit Galicji...

14 B. von Hirschausen et al., Phantomgrenzen: Räume und Akteure in der Zeit neu denken, Göttingen 2015.

15 J. Jańczak, Phantom Borders and Electoral Behaviour in Poland. Historical Legacies, Political Culture and their Influence on Contemporary Politics, „Erdkunde” 2015, vol. 69, nr 2, s. 125-137.

16 M. Šimon, Measuring Phantom Borders: The Case of Czech/Czechoslovakian Electoral Geography, „Erdkunde” 2015, vol. 69, nr 2, s. 139-150.

17 S. von Löwis, Phantom Borders in the Political Geography of East Central Europe: An Introduction, „Erdkunde”, vol. 69, nr 2, s. 99-106. 


\section{TOŻSAMOŚCI ZBIOROWE NA DAWNYCH POGRANICZACH}

Badanie bezpośredniego doświadczania pozostałości dawnych granic przez społeczności lokalne wymaga zastosowania odmiennej metodologii niż ta stosowana do analiz makrostrukturalnych, jak również zwrócenia uwagi na inne komponenty aktywności społecznej, które mogą stanowić przykłady przejawiania się dziedzictwa rozbiorowego. Już samo zdefiniowanie problemu badawczego, a w szczególności pojęcia granicy fantomowej, generuje problemy zarówno natury ontologicznej, jak i epistemologicznej. Status i oddziaływanie kordonu ponad 100 lat temu nie budzi potrzeby uzasadniania tego faktu, jednak odkrywanie jego funkcjonowania współcześnie, kiedy nie ma politycznej racji bytu, a jego przebieg wyznaczają jedynie wykopane przez zaborców rowy lub miejscami przepływająca Wisła i San, z których biegiem się on pokrywał, może wywoływać zdziwienie. We wprowadzeniu uzasadnialiśmy, że dawne podziały mają mniejsze bądź większe znaczenie dla życia społecznego, a zatem przejawianie się granic fantomowych może odzwierciedlać się nie tylko w reliktach materialnych, ale również w praktykach, w tym w używanym słownictwie. W związku z tym pojawia się konieczność wyodrębnienia takich komponentów funkcjonowania spoleczności lokalnych, które bezpośrednio lub pośrednio są powiązane z tymi elementami dziedzictwa rozbiorowego.

Granica stanowi zarówno układ obiektów materialnych, jak również generowanych przez nie znaczeń. Wisła jako fizyczna bariera dzieli pewną przestrzeń na dwa obszary i wyodrębnia dwie stereotypowo postrzegane zbiorowości społeczne: „parasoli” i „żółtobrzuchów". Odzwierciedlają się w tym najbardziej podstawowe sposoby rozumienia granicy zdefiniowane przez Fredrika Bartha, a zatem: dosłowne, jako bariery fizycznej dzielącej terytorium, ale również abstrakcyjne, pozwalające wyodrębnić i oddzielić od siebie grupy społeczne ${ }^{18}$. Według Georga Simmla, używającego metafory mostu i drzwi, praktyka łączenia przy jednoczesnym symbolicznym zaznaczaniu różnicy między dwiema kategoriami stanowi jeden z podstawowych elementów porządkowania przez ludzi otaczającej ich rzeczywistości ${ }^{19}$. Granica w takim ujęciu jest zatem zjawiskiem par excellence społecznym, elementem znaczącym i umożliwiającym generowanie kolejnych znaczeń; zawsze czyimś ${ }^{20}$, koniecznym do rozpatrywania $\mathrm{z}$ różnych perspektyw, w zależności od tego, dla kogo staje się elementem układu symbolicznego. Sama Galicja może być, czerpiąc z koncepcji Zygmunta Baumana ${ }^{21}$, potraktowana jako obszar płynnego pogranicza ${ }^{22}$, zacierając tym samym ostrość podziału między różnymi kulturami i uznając ten obszar jako skomplikowane połączenie odmiennych wzorów. Specyfiką pogranicza jest właśnie unikatowość systemów kulturowych, w obrębie których ele-

18 F. Barth, Boundaries and Connections, [w:] Signifying Identities. Anthropological Perspectives on Boundaries and Contested Values, London 2000, s. 17.

19 G. Simmel, Bridge and Door, „Theory Culture Society” 1994, vol. 11, s. 10.

20 F. Znaniecki, Metoda socjologii, przeł. i wstęp E. Hałas, Warszawa 2008, s. 68.

21 Z. Bauman, Społeczeństwo w stanie oblężenia, przeł. J. Margański, Warszawa 2006, s. 104.

22 J. Wierzejska, Idea Galicji..., s. 289. 
menty współwystępują lub łączą się, generując nowe, wyjątkowe wzory ${ }^{23}$. Wynika to z porowatości granic pozwalającej na przemieszczanie się wzorów między społecznościami zamieszkującymi obszary po obu ich stronach. Musimy jednak uwzględnić fakt, że interpretacje tego fragmentu monarchii austro-węgierskiej są różne w zależności od tego, czy tworzy je Polak, Ukrainiec czy też Austriak ${ }^{24}$. Postrzeganie tak rozległego terytorium $w$ kategoriach pogranicza ma znaczenie metaforyczne, $\mathrm{z}$ kolei obszary przyległe do granic Galicji i Królestwa Kongresowego stanowią konkretny teren badawczy, możliwy do bezpośredniej eksploracji przez zespół etnografów. Tutaj będą się konfrontować i łączyć odmienne perspektywy „żółtobrzuchów i „parasoli”.

Na poziomie lokalnym dochodzi nie tylko do „poziomego" ścierania się znaczeń wytwarzanych przez graniczące ze sobą kultury, ale również „pionowego”: tych podtrzymywanych przez społeczność miejscową z transmitowanymi z centrów globalnych, państwowych i regionalnych. W rezultacie tego nierównego konfrontowania aktorów ${ }^{25}$ powstają unikatowe systemy symboliczne, będące konglomeratami znaczeń lokalnych i ponadlokalnych ${ }^{26}$. Owa nierówność sił nie musi koniecznie oznaczać zaniku ideologii lokalnych na rzecz państwowo-narodowych, europejskich lub globalnych systemów symbolicznych. Badacze i teoretycy globalizacjii ${ }^{27}$ oraz lokalności ${ }^{28}$ wskazują, że tożsamości budowane na bazie małych ojczyzn mogą nieraz skutecznie opierać się koncepcjom narzucanym „z góry” i przeciwstawiać im swoje własne projekty, niemniej jednak w wyniku rozmaitych kanałów transmisji pozostają nieustannie w kontakcie z nimi. W tym również można doszukiwać się długiego trwania. Daje to szanse wyodrębniania wzorów lokalnych i ponadlokalnych, umożliwiając wyjście ponad poziom konkretu, porównywanie i tworzenie abstrakcji.

Próbując znaleźć punkt wyjścia do badania lokalności, przy jednoczesnym pozostawaniu „wrażliwymi teoretycznie” na kwestie przejawiania się ideologii narodowych lub państwowych, nie sposób nie zauważyć różnego rozkładania przez badaczy akcentów na cechy wyodrębniające rozmaitego typu doświadczenia wspólnotowe. Lokalność wiąże się z doświadczeniem bliskości, bezpośredniości, codzienności, konkretności odzwierciedlających się w tradycyjnym postrzeganiu przez socjologów

23 D. Wojakowski, Polacy i Ukraińny. Rzecz o pluralizmie i tożsamości na pograniczu, Kraków 2002, s. 25. Tenże, O technice malowania obrazów, czyli teoretyczne dylematy socjologii pogranicza, „Przegląd Polonijny" 2002, nr 3, s. 39-56.

24 T. Borejza, Mit Galicji..., s. 24.

25 A. Gupta, J. Ferguson, Discipline and Practice: "The Field" as Site, Method, and Location in Anthropology, [w:] Anthropological Locations, Boundaries and Grounds of a Field Science, red. A. Gupta, J. Ferguson, Berkeley 1997, s. 35.

26 J. Kurczewska, Dwie ideologie lokalności z narodem w tle, „Kultura i Społeczeństwo” 2003, nr 3. Taż, Robocze ideologie lokalności. Stare i nowe schematy, [w:] Oblicza lokalności. Tradycja i wspótczesność, red. J. Kurczewska, Warszawa 2004. D. Wojakowski, Kultura lokalna, czyli węzet symboliczny, [w:] Oblicza lokalności. Różnorodność miejsc i czasu, red. J. Kurczewska, Warszawa 2006. M. Kempny, „Kultura lokalna” w świecie kulturowych hybryd, „Kultura Współczesna” 2004, vol 42, nr 4, s. 64-83.

27 R. Giulianotti, R. Robertson, Forms of Glocalization: Globalization and the Migration Strategies of Scottish Football Fans in North America, „Sociology” 2007, nr 41, s. 133-152. 
Gemeinschaft ${ }^{29}$ lub solidarności mechanicznej ${ }^{30}$. Nowoczesny (modernistyczny) naród to wspólnota wyobrażona ${ }^{31}$, spajana przez wytwarzane przez ideologów przekonanie o wspólnej historii, więzi krwi lub kulturze ${ }^{32}$. Wyodrębnianie określonej społeczności lokalnej łączy się ze wskazaniem jej korelatów, które w pierwszym rzędzie mają charakter fizyczny, namacalny. Należą do nich kategorie przestrzeni, obiektów (w tym architektury i upamiętnień) oraz praktyk rozumianych jako przemieszczanie w przestrzeni. Dopiero na etapie badań terenowych można wyodrębnić całokształt systemów symbolicznych wytwarzanych i podtrzymywanych przez tę społeczność, łączonych z elementami przestrzeni fizycznej. Oczywiście nie znaczy to, że środowisko fizyczne jest w danym przypadku pierwotne względem kultury, a jedynie, że spostrzeżenie nośnika danego symbolu wyprzedza fakt rozpoznania i rozszyfrowania generowanych przezeń znaczeń.

$\mathrm{Na}$ gruncie socjologii ten związek między ludnością a zamieszkiwaną przez nią przestrzenią ma długą historię, jeśli przywołać pisma Hippolyte’a Taine’a'a ${ }^{33}$, koncepcję podłoża historycznego Ludwika Krzywickiego ${ }^{34}$, teorię społecznego wytwarzania przestrzeni Henriego Lefebvre'a ${ }^{35}$ czy wreszcie postrzeganie przez Stanisława Ossowskiego ojczyzny prywatnej jako „ziemi rodzinnej”, kojarzonej z przeszłymi pokolenia$\mathrm{mi}$ i miejscem urodzenia ${ }^{36}$. Istotna jest tutaj również koncepcja podłoża społecznego Kazimierza Dobrowolskiego, a zwłaszcza wyodrębnione przezeń w jej ramach czynniki geograficzne, obejmujące czynniki fizyczne, w tym materialne pozostałości zabudowań, układów przestrzennych gospodarstw, specyfikę krajobrazu itd. ${ }^{37} \mathrm{Z}$ kolei Joanna Kurczewska $^{38}$, odnosząc się do badań z pogranicza socjologii i antropologii społeczno-kulturowej, skoncentrowała się na zespoleniu przez Ossowskiego w koncepcję ojczyzny prywatnej tradycji Gemeinschaft z kryteriami przestrzennymi, uwzględniającymi perspektywę życia codziennego i styczności zarówno z osobami, jak i przedmiotami strukturyzującymi ową przestrzeń ${ }^{39}$. Nakreślając problematykę współczesnych badań małych ojczyzn, uczona postuluje przeniesienie uwagi na przestrzeń codzienną jednostki, jej korelaty emocjonalne i materialne. Badacza szukającego inspiracji

29 F. Tönnies, Community and Civil Society, Cambridge 2001.

30 E. Durkheim, The Division of Labour in Society, London 1994.

31 B. Anderson, Wspólnoty wyobrażone. Rozważania o źródtach i rozprzestrzenianiu się nacjonalizmu, przeł. S. Amsterdamski, Warszawa 1997. E. Hobsbawm, Introduction: Inventing Tradition, [w:] The Invention of Tradition, red. E. Hobsbawm, T. Ranger, Cambridge 2000.

32 F. Znaniecki, Wspótczesne narody, przeł. Z. Dulczewski, wstęp J. Szacki, Warszawa 1990.

33 H. Taine, Filozofia sztuki, przeł. A. Sygietyński, Warszawa 1896, s. 9.

34 L. Krzywicki, Rozwój spoteczny wśród zwierząt i u rodzaju ludzkiego, „Świat i Człowiek” 1913, nr 4, s. 46.

35 B. Jałowiecki, Spoteczne wytwarzanie przestrzeni, Warszawa 2010, s. 19-20.

36 S. Ossowski, O ojczyźnie i narodzie, Warszawa 1986.

37 K. Dobrowolski, Teoria podtoża historycznego, [w:] tegoż, Studia z pogranicza historii i socjologii, Wrocław 1967, s. 11.

38 J. Kurczewska, Kreacje matych ojczyzn, „Societas/Communitas” 2015, vol. 19-20, nr 1-2, s. 52.

39 S. Ossowski, O ojczyźnie... 
w pracach Ossowskiego zachęca ona do uważniejszego spojrzenia na bogactwo obiektów materialnych znajdujących się w ramach interesującej ich przestrzeni lokalnej ${ }^{40}$. Jednakowoż, przyjmując punkt widzenia włączający tożsamości mieszkańców badanych miejscowości, należy patrzeć zarówno na komponenty przestrzenne, jak i czasowe. „Odwieczne" posiadanie danego terytorium stanowi bowiem silny element integrujący i konstruujący tożsamości zbiorowe ${ }^{41}$. Konieczne jest uwzględnienie kryteriów codzienności i odświętności obejmujących obserwowalne praktyki społeczne mieszkańców podejmowane wokół przedmiotów. Poza tym, w rekonstruowaniu tożsamości społecznych pojawia się sposób klasyfikowania grup społecznych z zajmowanym przez nie obszarem (co poniekąd wiąże się ze stereotypowym postrzeganiem „innych” wskazanym we wstępie). Również poprzez codzienne poruszanie się w ramach małej ojczyzny otaczający obszar zaczyna postrzegać się jako „swój”, a jego mieszkańców częściej jako grupę odniesienia ${ }^{42}$. Bycie uczestnikiem grupy wiąże się z uprawnieniami do korzystania z danej przestrzeni, a brak takiego zezwolenia uniemożliwia lub ogranicza poprawne wykonywanie swoich funkcjonalnie wyodrębnionych obowiązków ${ }^{43}$. W odniesieniu do kwestii czasu, obok historycznego, chronologicznego jego postrzegania, istnieje kryterium antropologiczne, cykliczne. Skłania to do wyodrębnienia kategorii codzienności i odświętności, pozwalających porządkować badaczowi zarówno przedmioty, jak i przestrzeń. W rozwinięciu koncepcji Lefebvre’a Bogdan Jałowiecki uwzględnia podział na przestrzenie a) produkcji (rolniczej i pozazarolniczej); b) konsumpcji (reprodukcji siły roboczej); c) władzy; d) symboliki; e) wymiany ${ }^{44}$. O ile wszystkie z tych wyodrębnionych przestrzeni mogą stanowić element życia codziennego jednostki, tak przestrzeń symboliczna łączy się również z odświętnością, która może być ewokowana zarówno poprzez czynniki temporalne, jak i fizyczne. Rocznice bitew pierwszej wojny światowej czy odzyskania niepodległości lub sakralizacja przestrzeni poprzez tworzenie obiektów podtrzymujących pamięć społeczną tworzą kompleks zjawisk kształtujących tożsamości zbiorowe.

Uwzględnianie przeszłości w badaniu społeczności lokalnych odnosi się zatem zarówno do komponentów materialnych, jak też symbolicznych. Skoncentrujemy się na tych pierwszych, uznając, że nawet w swej reliktowej formie są one nośnikami znaczeń. Elementy materialne łączą się zatem z omawianymi już kategoriami podłoża historycznego lub geograficznego. Każde pokolenie w obrębie społeczności lokalnej funkcjonuje w przestrzeni wyznaczanej przez działania poprzednich pokoleń, w tym wśród materialnych obiektywizacji tych praktyk: układów przestrzennych, architektury,

40 J. Kurczewska, Kreacje..., s. 52.

41 B. Szacka, Czas przeszty, pamięć, mit, Warszawa 2006, s. 111.

42 D. Porczyński, Realne i wirtualne kręgi spoteczne. Socjologiczna analiza użytkowników gier fabularnych, Rzeszów 2014, s. 378. Maszynopis pracy doktorskiej.

43 F. Znaniecki, Grupy spoteczne jako wytwory uczestniczacych w nich jednostek, [w:] J. Szacki, Znaniecki, Warszawa 1986; tenże, Relacje spoteczne i role spoteczne. Niedokończona socjologia systematyczna, przeł. i przedm. E. Hałas, Warszawa 2011; tenże, The Social Role of the University Student, Poznań 1997.

44 B. Jałowiecki, Spoteczne wytwarzanie..., s. 37-39. 
pomników, muzeów, kolekcji. Dziedzictwo stanowi nieraz punkt odniesienia dla konstruowania tożsamości lokalnych i kreowania wizerunku lokalności w relacjach z otoczeniem $^{45}$. Należy zaznaczyć, że dziedzictwo kulturowe jako ogół spuścizny historycznej (obiektów, postaci, wydarzeń itd. ${ }^{46}$ danego obszaru nie stanowi całokształtu elementów wykorzystywanych w praktykach społecznych. Dla współczesnych działań istotna jest ich selekcja, a podtrzymywanie tych celowo dobranych elementów Jerzy Chłopecki nazywa „tradycją" ${ }^{\prime 7}$. W takim ujęciu widoczna jest zatem analogia między tradycją a pamięcią społeczną. Zarówno pierwsza, jak i druga wymaga ram wytwarzanych przez zbiorowości, jak również obie opierają się na doborze, podtrzymywaniu i „zapominaniu” pewnych elementów w przekazie i praktykach grupowych ${ }^{48}$. Wysadzenie soboru św. Aleksandra Newskiego w Warszawie, demontaż pomnika Karola Świerczewskiego w Jabłonkach, usuwanie macew z kirkutów podczas drugiej wojny światowej to działania, które można nazwać „czynnym zapominaniem”. Warto się w odniesieniu do tego zastanowić, czy usuwanie granic stanowi podobny rodzaj działania. Stanisław Myszka przywołuje relację dotyczącą znoszenia granic rozbiorowych w okolicach Radomyśla nad Sanem i Zaklikowa. Było to zorganizowane m.in. przez ks. Eugeniusza Okonia przedsięwzięcie, rozpoczynające się 2 listopada 1918 r. w Radomyślu wiecem, który następnie przeniósł się pod nieistniejącą już wieś Brzóza. Tam wykopano, przeniesiono i wkopano ponownie pod kościoły w Radomyślu i Zaklikowie żeliwne słupy graniczne ${ }^{49}$.

Pozornie uroczystość ta miała podobny cel jak usuwanie prawosławnej świątyni, monumentu poświęconego komunistycznemu dowódcy lub tablic upamiętniających Żydów. Jednak słupy graniczne, które usunięto z dawnej granicy i przeniesiono do Ra-

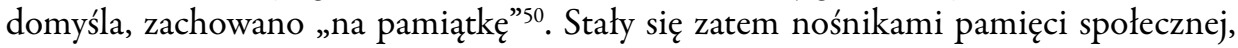
a ich pierwotne znaczenie symboliczne uległo przekształceniu. Inny sposób przezwyciężenia dziedzictwa rozbiorowego dokonał się w Kopkach, gdzie austriacką komorę celną rozebrano, a na jej miejscu, z materiałów pozyskanych z jej rozbiórki, zbudowano kościól. Trudno jednoznacznie zinterpretować ten fakt, być może był to przejaw pragmatyzmu, a może akt łączący elementy patriotyczne z religijnymi.

Zarządzanie pamięcią stanowi integralną część procesów konstruowania tożsamości. To, co zbiorowość uznaje za warte zapamiętania, a co za warte zapomnienia, łączy

45 D. Porczyński, Rola muzeów w budowie konkurencyjności samorządów lokalnych województwa podkarpackiego, „UR Journal of Humanities and Social Sciences” 2017, nr 3, s. 65-89.

46 G. Ashworth, Planowanie dziedzictwa, przeł. M. Duda-Gryc, Kraków 2015. A. Tomaszewski, Ku nowej filozofii dziedzictwa, Kraków 2012.

47 J. Chłopecki, Czas, świadomość, historia, Warszawa 1989.

48 M. Halbwachs, On Collective Memory, Chicago 1992. J. Nowak, Spoteczne reguty pamiętania. Antropologia pamięci zbiorowej, Kraków 2011.

49 S. Myszka, Radomyśl nad Sanem. Dzieje miasta i parafii, Stalowa Wola 2004, s. 190-191. Warto dodać, że obecnie pod radomyską dzwonnicą znajduje się jedynie fragment jednego słupa, a jak informuje tablica umieszczona na rynku, przeniesiono właśnie jeden słup, podzielony na trzy części. Nie wiadomo, gdzie znajdują się pozostałe.

s0 Warto dodać, że pod kościołem w Zaklikowie również znajduje się wyeksponowany austriacki słup. 
się bezpośrednio z pożądaną strukturą tożsamości. Procesy zarządzania pamięcią intensyfikują się szczególnie w okresach zmian, transformacji i „nowych początków”" Pozostawianie nośników pamięci w postaci słupów granicznych wydaje się rodzajem „aktu założycielskiego” nowej wspólnoty narodowej, niewymazującym jednakże 123 lat niewoli. Wprawdzie uroczystość sprzed 100 lat i zniesienie granic można potraktować jako otwarcie nowego rozdziału w historii Polski, jednak zaklikowski i radomyski słup pozostał „zakładką" tkwiącą symbolicznie w rozdziale poprzednim i przestrzegającą przed tym, co było.

Ostatnim omówionym sposobem upamiętniania dawnych granic są obiekty, które Marian Golka nazwał implantami pamięci ${ }^{52}$. Są to obiekty nieautentyczne, mające jednak na celu przywoływanie zjawisk z przeszłości. Jako przykład można podać rekonstrukcję przejścia granicznego z okolic wsi Dąbrowa Rzeczycka, gdzie przy wsparciu gminy postawiono austriackie i rosyjskie budki strażnicze i szlabany. Twórcy nie ukrywają przy tym faktu, że granica przebiegała w innym miejscu, a sam wygląd rosyjskiego słupa granicznego został wyestetyzowany ${ }^{53}$. Miejsce leży tuż przy drodze wojewódzkiej nr 855, jest zaopatrzone w miejsce parkingowe i ławki, zachęcając w ten sposób przejeżdżających do chwilowego zatrzymania się. Stanowi ono obecnie przestrzeń, w której odbywają się uroczystości patriotyczne. Przypomina to zabiegi przeprowadzone przez mieszkańców kaszubskiego Nadola, nieopodal którego przebiegała przedwojenna granica Polski i III Rzeszy. Słupki graniczne umieszczono w innej niż historyczna lokacji dla wygody turystów. W dialogu prawdy historycznej i rynku wygrał ten drugi ${ }^{54}$.

W przestrzeni geograficznej granice rozbiorowe przestały istnieć. Utrwaliły się natomiast w praktykach społecznych oraz w poświęconych im „miejscach pamięci”. Przetrwały w formie szczątkowej, w postaci rowów, dawnych obiektów strażniczych lub komór celnych oraz przeniesionych słupów. W postaci praktyk obserwowalne są w języku i sposobach porządkowania otaczającej rzeczywistości. Należy przy tym pamiętać, że wytwarzanie i podtrzymywanie znaczeń nie stanowi immanentnej cechy granicy, lecz rezultat praktyk społecznych. Przekładając to na dyrektywy metodologiczne, należy przyjąć, że w badaniach mikro- i mezosocjologicznych małych ojczyzn pozostających w ścisłych relacjach z granicami reliktowymi w miejsce wyrażonych liczbowo syntetycznych wskaźników należy wykorzystać - odnosząc się do Brunona Latoura ${ }^{55}$ - splatające się i wzajemnie na siebie oddziałujące kompleksy obiektów materialnych, wyobrażeń i praktyk. Skłania to do ukierunkowania naszej uwagi na metody etnograficzne, opierające się na długotrwałym przebywaniu w terenie i towarzyszeniu członkom społeczno-

51 J. Nowak, Spoteczne reguty..., s. 54.

52 M. Golka, Pamięć spoteczna i jej implanty, Warszawa 2009, s. 161.

53 Z. Surowaniec, Na granicy gmin powstata rekonstrukcja przejścia granicznego z okresu rozbiorów, „Echo Dnia", [online] http://www.echodnia.eu/podkarpackie/wiadomosci/stalowa-wola/art/8480478,na-granicy-gmin-powstala-rekonstrukcja-przejscia-granicznego-z-okresu-zaborow,id,t.html, 2 III 2018.

54 M. Sacha, $Z$ biegiem Piaśnicy. Miejsca pamięci wokót "granicy fantomowej” na Pótnocnych Kaszubach, „Przegląd Zachodni” 2014, vol. 352, nr 3, s. 169-170.

55 B. Latour, Reassembling the social. An introduction to Actor-Network Theory, New York 2005, s. 71. 
ści w codziennych i odświętnych praktykach, obserwowaniu ich działań łączących się z miejscami pamięci, rejestrowaniu formy i tematów wypowiedzi. Warto w tym miejscu jednak zaznaczyć, że dotychczasowe rozważania odnosiły się przede wszystkim do miejsc i działań odbywających się na otwartej przestrzeni. Dla zrozumienia faktu trwania granic rozbiorowych mają również znaczenie praktyki ukierunkowane na obiekty „małe” oraz składające się z nich kolekcje. Wymaga to zatem szczegółowego omówienia.

\section{KOLEKCJE JAKO OBRAZY SPOŁECZNOŚCI}

Uznając istotność relacji między człowiekiem a środowiskiem, nie sposób nie zauważyć, że zbiorowość zamieszkująca dane terytorium jest warunkowana nie tylko przez jego specyfikę, ale sama również przekształca je, dostosowując do własnych potrzeb. Układ taki - z perspektywy grupy - jest w zasadzie odzwierciedleniem koncepcji kultury Clifforda Geertza jako zjawiska niebędącego wyłącznie wytworem człowie$\mathrm{ka}$, ale raczej współkształtującego go ${ }^{56}$. Współwystępowanie i wzajemne oddziaływanie społeczności i najbliższego kontekstu jej funkcjonowania, którego badanie jest tak istotne dla antropologii społeczno-kulturowej ${ }^{57} \mathrm{i}$ jakościowo zorientowanej ku socjologii ${ }^{58}$, odnosi się również do bliskiej relacji między jednostką a przedmiotami umiejscowionymi w jej przestrzeni życia codziennego. Geertzowska koncepcja wzajemnego oddziaływania człowieka i kultury uwidacznia się w opisywanej przez Marka Krajewskiego relacji między jednostką a przedmiotem. Człowiek nie tylko nauczył się wytwarzać przedmioty do realizacji różnych potrzeb, ale długotrwałe użytkowanie przedmiotów sprawiło, że stały się one wyznacznikiem człowieczeństwa $^{59}$. Wiele ról społecznych może być identyfikowanych właśnie poprzez powiązane z nimi przedmioty. Żołnierza rozpoznaje się przez jego wyposażenie. To ono go w zasadzie „stwarza” ${ }^{60}$. Można zatem stwierdzić, że przedmioty stanowią - używając pojęcia z zakresu metodologii nauk społecznych - wskaźniki pewnych zjawisk społecznych $^{61}$. W zależności od przyjmowanej perspektywy epistemologicznej można przyjąć, że bądź samo zarejestrowanie obecności danego obiektu niesie ze sobą wartość poznawczą, bądź potwierdzenie jego obecności staje się dopiero punktem wyjścia do dalszych operacji badawczych, mających na celu ustalenie jego cech lub znaczeń, które przenosi. Ta druga perspektywa przypomina posiłkowanie się fotografiami lub nagraniami w prowadzeniu wywiadów pogłębionych, w niektórych

\footnotetext{
56 C. Geertz, Interpretacja kultur. Wybrane eseje, przeł. M.M. Piechaczek, Kraków 2005, s. 66-67.

57 Tamże, s. 27.

58 K. Charmaz, Teoria ugruntowana. Praktyczny przewodnik po analizie jakościowej, przeł. B. Komorowska, Warszawa 2009, s. 24.

59 M. Krajewski, Sq̨ życiu rzeczy... Szkice z socjologii przedmiotów, Warszawa 2013.

60 A. Gell, Art and Agency, Oxford 1998, s. 20.

61 S. Nowak, Metodologia badań spotecznych, Warszawa 2010, s. 165.
} 
aplikacjach socjologii wizualnej ${ }^{62}$. Według Krajewskiego przedmiot utrwala pewien system kulturowy, który doprowadził do wytworzenia tego obiektu, a poprzez używanie artefaktów człowiek uczestniczy w życiu społecznym ${ }^{63}$. W sukurs przychodzi mu również nowa muzeologia, w której dyskursie przedmioty są traktowane jako źródło wiedzy nie tylko o nich samych, ale i o szerszych procesach: tych, które doprowadziły do ich wytworzenia i tych, które są ich rezultatem ${ }^{64}$.

Obojętnie, czy rejestrowanie przedmiotów staje się punktem wyjścia do poszukiwania zależności statystycznych, czy też zrozumienia znaczeń przez nie przenoszonych, należy przyjąć, że wraz z identyfikacją kolejnych obiektów użytkowanych przez daną społeczność powstaje coraz bardziej wyraźny obraz różnych segmentów jej kultury. Im bardziej kompletna jest lista elementów materialnych, tym więcej wiadomo na temat zbiorowości. Nic zatem dziwnego, że James Clifford dostrzegł pewne analogie między kulturą a kolekcją, porównując następnie badania etnograficzne z kolekcjonowaniem. Według niego takie postrzeganie etnografii pozwala lepiej zrozumieć, jak doświadczenia i fakty sa wybierane, gromadzone, odrywane od sytuacji istniejacych w konkretnym czasie i w jaki sposób nadawana jest im trwata wartość w nowym uktadzie ${ }^{65}$. Kolekcjonowanie wiąże się z selekcją i postępowaniem według określonych procedur, a obserwacja doświadczeń badaczy „zachodnich” pozwala stwierdzić, że wybiera się najczęściej elementy, które „zasługują” na włączenie w zakres tworzonych zbiorów. Co istotne w kontekście niniejszego tekstu, antropologowie najczęściej gromadzą elementy identyfikowane jako „tradycyjne" ${ }^{66}$. Można zatem w odniesieniu do tego zaobserwować pewną prawidłowość funkcjonowania kultury jako takiej. Zarówno społeczności, jak i ich badacze klasyfikują elementy rzeczywistości, a następnie podejmują działania mające na celu utrwalanie tych uznanych za najcenniejsze. Pamięć społeczna i tradycja stanowią systemy elementów „zapamiętanych” i „kultywowanych” przez daną zbiorowość. Etnografowie z kolei, opierając się na ustalonych metodach, dokonują ponownej selekcji symboli, próbując - jak Margaret Mead z eseju Clifforda „skompletować” całość kultury danej społeczności bądź wybranego w toku przygotowania projektu jej fragmentu.

Fakt selekcjonowania przedmiotów zmusza do ponownego zastanowienia się nad kwestią życia codziennego i pamięci społecznej. Wyjątkowość pewnych obiektów może się kłócić z powtarzalnymi, „zwyczajnymi” praktykami jednostek i zbiorowości. Krajewski definiuje kategorię „ulubionych” przedmiotów: naczyń, piór, długopisów, krzeseł itd., które w jakiś sposób dopełniają używające je jednostki, porządkując

62 K. Konecki, Wizualna teoria ugruntowana. Podstawowe zasady i procedury, „Przegląd Socjologii Jakościowej” 2012, vol. 8, nr 1, s. 29. D. Byczkowska, Ciato w tańcu. Analiza socjologiczna, Łódź 2012, s. 21-22.

L. Jordanova, Objects of Knowledge: A Historical Perspective on Museums, [w:] The New Museology, red. P. Vergo, London 1989, s. 23.

65 J. Clifford, Ktopoty z kultura. Dwudziestowieczna etnografia, literatura i sztuka, przeł. E. Dżurak i in., Warszawa 2000, s. 249.

66

Tamże, s. 250. 
codzienne doświadczenia ${ }^{67}$. Socjolog dodaje również kolejny zbiór: pamiątek - pozwalających podtrzymywać relacje z bliskimi lub przywołujących pamięć o dawnych pokoleniach, będących zatem zindywidualizowanymi nośnikami pamięci społecznej. Znajdują się one w sytuacji odmiennej niż obiekty poddane muzealizacji, tj. eksponaty. Krajewski pisze, że wystawianie przedmiotów w muzeum ma na celu zastanowienie się nad ich rolą w ludzkim świecie i badanie przemian w kulturze. Badania i muzealizacja pozwalają dowiedzieć się o nich więcej, ale jednocześnie wyłączają je $\mathrm{z}$ życia codziennego ${ }^{68}$. Taki sposób instytucjonalizacji można uznać za rodzaj sakralizacji przedmiotu, zmiany jego statusu, odebrania mu funkcji użytkowej i nadania symbolicznej. W ten sposób włącza się go w obręb praktyk odświętnych, które odnoszą się nie tylko do jednostki, ale całej wspólnoty lokalnej. Komponuje się to z założeniami nowej muzeologii, w świetle których muzeum przestało być wyłącznie kolekcją, ale stanowi również system praktyk skoncentrowanych zarówno na obiektach, jak i na otoczeniu. Są to działania związane z trzema wyodrębnionymi funkcjami instytucji: ochrona, badanie, informowanie ${ }^{69}$. Pierwsza z nich łączy się z sakralizacją przedmiotu uznanego za istotny dla muzealnika lub dla grupy. Druga - z interesującej nas perspektywy - odnosi się do odczytywania jego znaczeń, poszukiwania relacji artefaktu z otoczeniem. Trzecia to interpretowanie obiektu, które ma na celu zbliżenie jego i widzów, ułatwienie zrozumienia, budowanie obrazu lokalności i próbę wkomponowania tego wizerunku w ramy konstruowane przez członków społeczności lokalnej. To oczywiście komplikuje prosty, jak mogłoby się wydawać, podział na praktyki i przedmioty. Uzmysławia, że obiekty zawsze są odczytywane w kontekstach, które zmieniają ich znaczenie w zależności od tego, co się na nie składa ${ }^{70}$. Selekcjonując, konserwując, klasyfikując, interpretując i upowszechniając eksponaty członkom społeczności lokalnych, muzea budują ramy podtrzymujące obrazy przeszłości, będąc tym samym kolejnym miejscem pamięci.

Należy pamiętać, że muzea rzadko posługują się pojedynczymi eksponatami. W kontekście instytucjonalnym stanowią one części składowe szerszych układów: kolekcji lub ekspozycji (co oczywiście nie przeszkadza być im częścią i jednej, i drugiej). Przyglądając się zatem artefaktowi, należy uwzględnić jego powiązanie z przeszłością i teraźniejszością zarazem. Kolekcja nie stanowi wylącznie formy klasyfikowania i opisu elementów składających się na nią, ale po ich połączeniu jest również formą narracji o wycinku rzeczywistości, której dotyczy. W ten sposób wytwarza się system powiązań między przeszłością i teraźniejszością, obiektem a systemem obiektów. Przedmioty, których nieraz jedyną namiastką związku ze sobą jest użytkowanie przez dawnych członków wspólnoty lokalnej, są współcześnie zestawiane ze sobą i na tej podstawie

\footnotetext{
M. Krajewski, Sqq $w \dot{z y c i u \ldots, ~ s . ~} 13$.

Tamże.

69 S.E. Weil, Rethinking the Museum: An Emerging New Paradigm, [w:] Reinventing the Museum, red. G. Anderson, Lanham 2004, s. 74-75.

70 C.S. Smith, Museums, Artefacts, and Meanings, [w:] The New Museology, red. P. Vergo, London 1989, s. 6-21.
} 
odtwarza się czy raczej wytwarza ich system powiązań zapośredniczony przez współczesne wyobrażenia na temat przeszłości.

Krzysztof Pomian zauważa, że już XVII-wieczne gabinety osobliwości były rodzajem mikrokosmosu, „kompendium wszechświata”71. Z kolei Peggy Levitt pisze, że od udostępnienia kolekcji Luwru publiczności muzea odgrywają istotną rolę w integrowaniu narodów i budowania ich wizerunków ${ }^{72}$. Badaczka, używając metafory, stwierdza, że muzea umieściły naród i świat na wystawie. Rozwijając tę myśl, warto odnieść się do koncepcji kultury jako kolekcji Clifforda. Zestawiając poszczególne eksponaty stanowiące elementy kultury i uzupełniając je podpisami, wytwarza się pewien jej obraz. Może to być obraz narodu, ale również regionu, czemu według narracji samych muzealników służą muzea regionalne ${ }^{73}$. Wystawy mogą również podtrzymywać pamięć ziemi dzieciństwa, raju utraconego w wyniku przesuwania granic politycznych ${ }^{74}$.

Do rozwinięcia tezy o budowaniu przez ekspozycję obrazu społeczności konieczne jest ponowne przywołanie koncepcji eksponatu-wskaźnika. Z perspektywy ekspozycji istotna jest nie tylko jego obecność jako obiektu fizycznego, ale całokształt znaczeń, które przenosi. Pomian zaproponował wprowadzenie dla tego rodzaju przedmiotów nazwy „semioforów”. Pisze on, że semiofory włączają się w wymianę między uczestnikami interakcji oraz między widzialnym a niewidzialnym. Wynika to $z$ faktu odsyłania przez nie do czegoś aktualnie niewidzialnego, czego nie można wskazać gestem, a jedynie nazwać lub omówić słowami ${ }^{75}$. Aleida Assmann rozwija koncepcję Pomiana, tworząc typologię semioforów umieszczonych w kontekście muzeum. Uczona podkreśla fakt, że przedmioty mogą być nośnikami pamięci, a istota muzeum opiera się właśnie na tym przeświadczeniu ${ }^{76}$. Analizując wystawy poświęcone wypędzeniom, Assmann proponuje wyodrębnienie trzech typów semioforów: a) autentyczne świadectwa o wartości historycznej, uosabiające rzeczywistość, do której się odnoszą - mapy, dekrety, paszporty; b) relikty historyczne, niemające rangi symbolu, uzupełniające jedynie opowiadaną historię - wózek lub fragment baraku zamieszkiwanego przez uchodźców; c) osobiste pamiątki, w których konkretyzują się indywidualne losy i cierpienia - np. uszyta z gazy sukienka komunijna lub pęk kluczy ${ }^{77}$.

Problematyka omawianej wystawy wiąże się częściowo z istotą granicy, której celem jest zatrzymanie migracji lub umożliwienie jej wyłącznie osobom dysponującym prawnie usankcjonowanym pozwoleniem: paszportem lub przepustką. Typologia Assmann

71 K. Pomian, Collectors and Curiosities. Paris and Venice 1500-1800, Cambridge 1990, s. 48.

72 P. Levitt, Artifacts and Allegiances. How Museum Put the Nation and the World on Display, Oakland 2015, s. 2.

73 D. Porczyński, Muzea podkarpackie 2004-2014. Globalizacja i europeizacja a przeobrażenia lokalnych instytucji kultury, Rzeszów 2016, s. 70.

74 M. Sacha, Fantomowe dziedzictwo? Różnice w muzealnej prezentacji dziedzictwa niemieckiego wschodu oraz polskich Kresów - próba diagnozy, „Rocznik Antropologii Historii” 2016, nr 9, s. 147-170.

75 K. Pomian, Historia. Nauka wobec pamięci, Lublin 2006, s. 124.

76 A. Assmann, Kreowanie obrazu przesztości w muzeach, [w:] taż, Między historia a pamięcia. Antologia, przeł. P. Pieńkowska-Wiederkehr, red. nauk. i posł. M. Saryusz-Wolska, Warszawa 2013, s. 253-254.

77 Tamże. 
może zatem stanowić punkt wyjścia do porządkowania elementów składających się na materialne dziedzictwo granic rozbiorowych. W kolekcjach zinstytucjonalizowanych - muzeach - lub w prywatnych, w zbiorach pamiątek rodzinnych, ale też w zasobach internetowych można znaleźć różne obiekty będące semioforami granicy fantomowej. Najmniejszy problem stanowi pierwszy typ, do którego można zaliczyć mapy przedstawiające przebieg granicy (ryc. 1), usytuowanie posterunków i komór celnych, ale też paszporty defluidacyjne, pozwalające na spławianie drewna flisakom z biegiem Sanu i Wisły do Gdańska. Włączanie kolejnych rodzajów obiektów wymaga odpowiedzi na pytanie, czy eksponatem jest obiekt znajdujący się w przestrzeni muzeum, czy też można za niego uznać wymienione już kilkakrotnie żeliwne słupy graniczne eksponowane w przestrzeni publicznej (ryc. 2). Zbiór przedmiotów istotnych z perspektywy tak pomyślanej kolekcji jest - póki co - otwarty. W tym miejscu można jedynie spekulować, co się w nim znajdzie, czy będzie to dokumentacja poszczególnych posterunków, umundurowanie, broń, fotografie przedstawiające znoszenie granic czy też inne eksponaty przywołujące osobiste doświadczenia mieszkańców regionu.

Ponowoczesne muzeum poprzez działania interpretacyjne, mediacyjne i upowszechnieniowe sprawia, że obiekty powiązane z przeszłością wpływają na współczesność. Jeśli w przeszłości funkcjonowanie granicy warunkowało praktyki społeczności, których komponentami były pewne przedmioty (np. wspomniany paszport defluidacyjny), to obiekty te, stanowiąc synekdochę kultury pogranicza Galicji i Królestwa Kongresowego, doświadczane współcześnie, stanowią jednocześnie komponent współczesnej społeczności lokalnej Gorzyc lub Stalowej Woli, który poprzez pamięć społeczną i reprodukowanie określonego systemu symbolicznego jest wyrazem trwania tej „dawnej” kultury.

Ryc. 1. Austriacka mapa wojskowa przedstawiająca przebieg granicy między wsiami Łążek Chwałowski i Łążek Zaklikowski

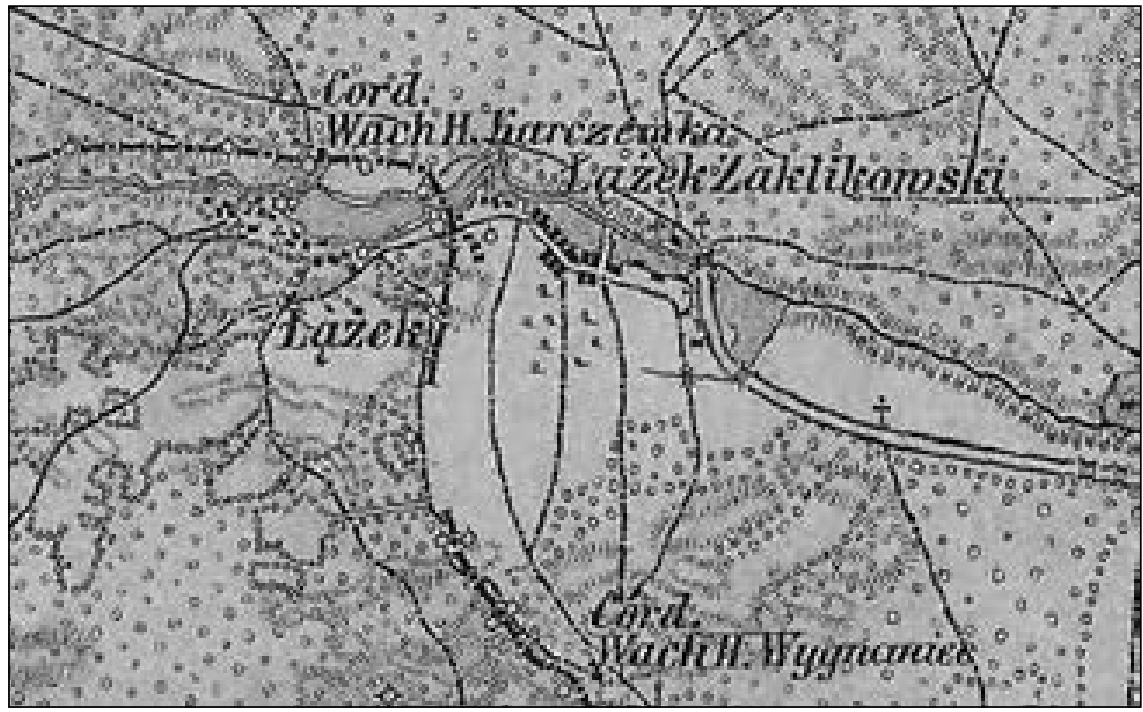

Źródło: http://mapire.eu/en/map/europe_1850-1890, 18 VII 2019 
Ryc. 2. Usuwanie słupów na granicy zaborów pod wsią Brzóza (2 listopada 1918)

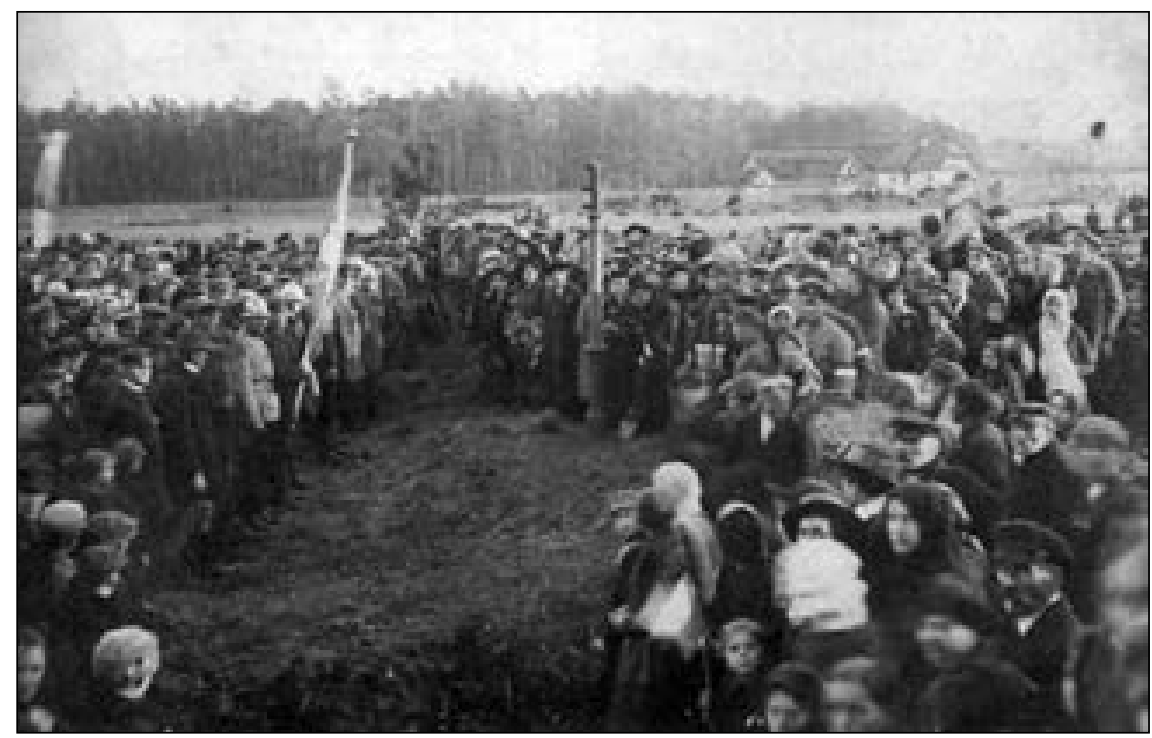

Źródło: S. Myszka, Radomyśl nad Sanem. Dzieje miasta i parafii, Stalowa Wola 2004

Kontakt z artefaktami zgromadzonymi w muzeach, archiwach lub kolekcjach prywatnych rozbudowuje zasoby wiedzy jednostki i może zmienić dotychczasową percepcję przestrzeni, w której dotąd ona funkcjonowała. To doświadczenie może budzić dysonans, zwłaszcza gdy zestawi się historyczną mapę Galicji z doświadczeniem Unii Europejskiej jako projektu umożliwiającego nieograniczone przekraczanie granic. Śledzenie fragmentu załączonego dokumentu uzmysławia różnice między rzeczywistością nie aż tak odległą a tą percypowaną na co dzień. Co więcej, wiedza ta dostarcza nowej ramy interpretacyjnej dla przestrzeni: tej wyrażonej symbolicznie na archiwalnej mapie, tej odtwarzanej z narracji szkolnej lub rodzinnej oraz tej współczesnej. Motywuje to do zadawania pytań o lokalność lub polskość.

Dokumenty wydawane przez władze zaborcze odgrywają podobną rolę do map. Paszport defluidacyjny znajdujący się w zbiorach Muzeum Regionalnego w Stalowej Woli pozwala prześledzić drogę flisaków od Gorzyc aż do Gdańska. Wystawiony w języku niemieckim i polskim druk zawiera również pieczęcie i adnotacje nanoszone w miejscowościach leżących nad Wisłą, z biegiem której poruszał się jego posiadacz. Analiza pozwala zauważyć, że Rozwadów - obecnie dzielnica Stalowej Woli - był niegdyś siedzibą cesarsko-królewskiego dystryktu, zaś w Nadbrzeziu - będącym obecnie częścią Sandomierza - znajdowała się austriacka komora celna. Poruszanie się na tak długim dystansie wymagało zapewne znajomości języka niemieckiego i rosyjskiego. Kontrast między obrazem rzeczywistości budowanym na podstawie tego dokumentu a rzeczywistością doświadczaną obecnie jest znaczny. Wskazuje on na zależności skali makro oraz mezo kształtujące ówczesną przestrzeń geograficzną, polityczną i społeczną. Po pierwsze, sugeruje inny układ administracyjny, projektowany poza centrami politycznymi 
uznawanymi obecnie za decyzyjne w sprawach polskiej polityki wewnętrznej. Po drugie, dostrzegalny jest fakt, że Sandomierz i Gorzyce, miejscowości oddalone w linii prostej od współczesnych granic Polski o ponad 250 kilometrów, były strefą pogranicza obcych mocarstw. Omawiany paszport zatem w jeszcze mocniejszy sposób ewokuje granicę fantomową, a dzięki datom wpisanym w uzyskiwanych przez właściciela zaświadczeniach pozwala na śledzenie procesu poruszania się przez ziemie podzielonej Polski, etapy uzyskiwania zezwoleń, potwierdzeń i co najważniejsze - przekraczania granic.

Fotografię, jako wskaźnik lub semiofor, cechują inne właściwości niż mapę czy dokument. Jednym z podstawowych założeń pozwalających wykorzystać archiwalne zdjęcie w procesie badawczym jest potraktowanie go nie jako obiekt estetyczny, lecz jako nośnik znaczen $^{78}$. W ten sposób zapisane na papierze światłoczułym elementy, pojedynczo lub w powiązaniu ze sobą, budują pewną narrację. Na zamieszczonej powyżej fotografii można wyodrębnić dwie składowe głównej sceny oraz tło. Najważniejsza figura znajduje się w centrum, gdzie widoczny jest austriacki słup graniczny, na prawo od którego znajduje się ubrany na czarno mężczyzna wbijający w ziemię łopatę (ks. Okoń?). Z kolei tłum zgromadzony wokół słupa jest wyraźnie podzielony na dwie grupy, które oddziela pas pustej przestrzeni. Trudno powiedzieć, czy jest on symbolicznym odwzorowaniem przebiegu granicy, czy też wynikiem aranżacji sceny przez fotografa. O tym drugim mogłoby świadczyć skierowanie przez większość uczestników wzroku w kierunku widza (w domyśle miejsca, w którym stał fotograf). W tłumie widoczni są dorośli i dzieci, przedstawiciele chłopstwa (w maciejówkach i chustach), a także mieszczaństwa (elegancko ubrane kobiety i mężczyźni, pierwsze i drudzy w kapeluszach). Rzucają się w oczy mężczyźni $\mathrm{w}$ hełmach stojący w pobliżu sztandaru (prawdopodobnie strażacy) oraz na prawo od słupa umundurowani mężczyźni w czapkach z emblematem i w dwukolorowych (biało-czerwonych?) opaskach na lewym ramieniu. Punktami charakterystycznymi są również chorągwie niesione przez uczestników. Jedną z nich widać na czele grupy stojącej po lewej stronie otwartej przestrzeni, drugą - nieco dalej, również wśród osób znajdujących się po lewej stronie. W tle widać las, a po prawej stronie zabudowania. Jest to zapewne wieś Brzóza, choć duże murowane budynki mogą sugerować, że jest to pobliski folwark lub komora celna. Strona, w którą jest zwrócony słup, sugeruje, że Galicja znajduje się na prawo, zaś zabór rosyjski na lewo. Zatem fotograf był zwrócony w kierunku południowym.

Interpretacja obrazu bez odnoszenia się do innych danych jest możliwa, ale dopiero próba odczytania go w powiązaniu z kontekstem oraz z innymi dokumentami pozwala zrozumieć, co się dzieje w zapisanej scenie. Dzięki zestawieniu z innymi fotografiami z kolekcji można dowiedzieć się, że to radomyślanie nieśli ze sobą przynajmniej jedną chorągiew: widoczną na zdjęciu po lewej stronie z wizerunkiem Matki Bożej Częstochowskiej. Mężczyźni w hełmach strażackich przybyli od strony Zaklikowa, zaś ci w opaskach - z Radomyśla (podpis pod jednym ze zdjęć sugeruje, że są to „ochotnicy” z Radomyśla). $\mathrm{Na}$ czwartej fotografii widać, że emblemat na ich czapkach to orzeł (związku strzeleckiego lub legionowy) i jednocześnie można zauważyć, że opaski są albo założone odwrotnie,

78 M. Bal, The Discourse of the Museum, [w:] Thinking About Exhibitions, red. R. Greenberg, B.W. Ferguson, S. Nairne, London-New York 1996, s. 205. 
albo mogą być flagą Habsburgów. Co więcej, zestawienie fotografii pozwala zrekonstruować pewien proces składający się na wydarzenia 2 listopada 1918 r.: „wiec w Radomyślu”, „wiec na granicy zaborów”, „wykopywanie słupów”, „powitanie chlebem i sola”.

Podstawową cechą wspólną map, dokumentów i fotografii jest to, że utrwalają pewien stan rzeczywistości występujący w chwili ich powstania. Oprócz tego jednak można zaobserwować znaczne różnice w desygnowaniu jej składowych. Po pierwsze, symbolizują one różne komponenty funkcjonowania pogranicza. Mapa poprzez abstrakcyjne symbole obrazuje jego komponenty geograficzne. Paszport i fotografia stanowią świadectwa odnoszące się do konkretnych osób i wydarzeń. Po drugie, mapa i fotografia są w tym wypadku statyczne. Rejestrują pewne momenty, podczas gdy paszport, rejestrując momenty, układa je w pewien proces. W przypadku mapy i zdjęcia byłoby to możliwe po porównaniu ich z odpowiadającymi im materiałami z różnych okresów, co na przykładzie fotografii przedstawiliśmy. Po trzecie, wszystkie te dokumenty pokazują interakcje (a raczej pewne ich momenty) między zaborcami a Polakami. Mapy odzwierciedlają np. praktyki radzenia sobie z polskimi nazwami przez niemiecko- i (na innej mapie) rosyjskojęzycznych kartografów oraz przekształcanie obszaru poprzez wprowadzanie własnych elementów kulturowych. Paszport jest świadectwem funkcjonowania Polaków w ramach administracyjnych narzuconych przez zaborców. Fotografia utrwaliła zaś interakcję z dziedzictwem carskim i habsburskim.

Jakie jednak znaczenie mają te historyczne obiekty dla procesów współczesnych? Będąc świadectwem swoich czasów, wytworzonym „kiedys'”, a trwającym „teraz”, stanowią łącznik między kulturą Galicji a teraźniejszością. Poprzez ich interpretację (np. w muzeum) stają się składowymi tożsamości lokalnych i praktyk codziennych oraz odświętnych. Jednak, co najważniejsze, odnosząc się jednocześnie do procesów zachodzących w pewnych wycinkach przestrzeni, pozwalają na nią patrzeć, używając ram „rozbiorowych” i „współczesnych”, budując tym samym kompleks pogranicza fantomowego.

\section{KRAJOBRAZY PAMIĘCI}

W rozważaniach dotyczących trwania dawnych granic rozbiorowych istotny element stanowią badania krajobrazowe, zmierzające do określenia stopnia zróżnicowania terenów rozdzielonych w przeszłości granicami państwowymi.

Krajobraz jest pojęciem wieloznacznym, posiadającym wymiar zarówno przestrzeni rzeczywistej, jak i nierzeczywistej ${ }^{79}$, stąd potrzeba uszczegółowienia sposobu interpretowania tego zagadnienia $\mathrm{w}$ kontekście poruszanego problemu. Pierwotna forma krajobrazu, wynikająca wyłącznie z procesów przyrodniczych, nasycana stopniowo elementami związanymi z działalnością człowieka, przekształciła się w krajobraz kulturowy, stanowiący zasadniczy przedmiot naszego zainteresowania. Zgodnie z definicją zawartą w Ustawie o ochronie zabytków i opiece nad zabytkami krajobraz kulturowy

79 J. Bogdanowski, Krajobraz zabytkowyjako wyraz tożsamości, „Teka Komisji Urbanistyki i Architektury” 1976, vol. 10, s. 16. 
to przestrzeń historycznie uksztattowana w wyniku dziatalności cztowieka, zawierająca wytwory cywilizacji oraz elementy przyrodnicze $e^{80}$. Krajobraz kulturowy, podobnie zatem jak przedmiot, stanowi wytwór działalności człowieka. Jednak zasadność rozdzielenia tych zagadnień w prowadzonych badaniach potwierdzają rozważania nad kulturą Jana Bruzdy, który dowodzi, że miejsce (krajobraz kulturowy, wnętrze krajobrazowe) jest pewnym obszarem, często jakimś terytorium czy terenem, przedmiot zaś określonym, zamkniętym w sobie obiektem występującym w danym miejscu ${ }^{81}$.

Według Janusza Bogdanowskiego krajobraz jest fizjonomiq środowiska [...] powstata w wyniku przemian geologicznych, przyrodniczych i kulturowych, które od wieków ksztattowaty postać otoczenia ${ }^{82}$. Uzmysławia to istnienie ciągłych przeobrażeń krajobrazu, wynikających z aktualnych uwarunkowań przyrodniczych i kulturowych ${ }^{83}$. W krajobrazie nieustannie dokonuje się oddziatywanie pomiędzy historia a miejscem, uchwytne odczucie przesztości. Jest to rodzaj relacji otwartej, swoista narracja krajobrazowa ${ }^{84}$. Poszczególne etapy przekształceń pozostają „zapisane” w przestrzeni w postaci różnorodnych form osiedli mieszkaniowych i ich elementów, krajobrazu rolniczego, krajobrazu postmilitarnego itp. ${ }^{85}$ Następujące nawarstwienie powoduje niekiedy zniekształcenie lub utracenie wcześniejszych komponentów, co stanowi zasadniczą trudność w badaniach krajobrazów historycznych, jakimi są także krajobrazy dawnych granic rozbiorowych.

Czytelność dziedzictwa kulturowego w krajobrazie oraz zdefiniowanie cech decydujących o jego indywidualności stanowi istotny element budowania lokalnej tożsamości w wymiarze przestrzennym i społecznym. Przywołane pojęcie tożsamości rozumiane jest jako zależność pomiędzy człowiekiem a percypowanym przez niego krajobrazem, który budują historycznie nawarstwione elementy treści (kultura, tradycja miejsca) i formy (kanon miejsca) ${ }^{86}$. Krajobraz codzienny, rodzimy, bliski pełni ważną funkcję w kształtowaniu postaw społecznych wyrażających się m.in. w odpowiedzialnym formowaniu środowiska życia. Związek człowieka z najbliższym otoczeniem posiada niekiedy postać bardzo silnej więzi, która przejawia się w przywoływanym już pojęciu ojczyzny prywatnej ${ }^{87}$. Potwierdza to sentymentalny obraz Litwy w Inwokacji Adama Mickiewicza ${ }^{88}$.

80 Ustawa z dn. 23 lipca 2003 o ochronie zabytków i opiece nad zabytkami, Dz. U. $2003 \mathrm{nr} 162$ poz. 1568, s. 2.

81 J. Bruzda, Kultura miejsca, „Teka Komisji Urbanistyki i Architektury” 1996, vol. 28, s. 81.

82 Tamże.

83 U. Myga-Piątek, Krajobrazy kulturowe. Aspekty ewolucyjne i typologiczne, Katowice 2012, s. 60.

84 A. Zachariasz, Krajobrazy pamięci wyrazem tożsamości miejsca, „Prace Komisji Krajobrazu Kulturowego" 2011, vol. 15, s. 310-326, [online] http://krajobraz.kulturowy.us.edu.pl/publikacje. artykuly/niematerialne/zachariasz.pdf, 7 III 2018.

85 A. Gajdek, B. Cieśla, Relikty uktadów ruralistycznych w strukturze wspótczesnego miasta. Zachowane dziedzictwo w kontekście zatożeń miasta przysztości, na przyktadzie Rzeszowa, „Journal of Civil Engineering, Environment and Architecture" 2017, vol. 34, nr 64, s. 67-78.

86 Z. Myczkowski, Krajobraz wyrazem tożsamości w wybranych obszarach chronionych w Polsce, Kraków 2003, s. 24.

87 S. Ossowski, O ojczyźnie..., s. 35.

88 A. Mickiewicz, Pan Tadeusz, Warszawa 2017, s. 7. 
Szczególnym rodzajem krajobrazu kulturowego jest interesujący nas tutaj najbardziej krajobraz dawnych granic międzypaństwowych, będący w przeszłości miejscem stykania się różnych kultur i narodowości. Podejmowane dotychczas prace badawcze potwierdzają istnienie zróżnicowania pograniczy, pomimo ustania pełnienia przez granicę roli bariery politycznej ${ }^{89}$. Zachowane ślady granicy miewają postać bezpośrednią (np. budynki straży granicznej, komory celne, drogi graniczne) lub niebezpośrednią, która ujawnia się w utrwalonej strukturze użytkowania ziemi, fizjonomii zabudowy i morfologii działki siedliskowej czy w świadomości i postawach mieszkańców (co wynika z historycznej przynależności obszarów do różnych organizmów politycznych ${ }^{90}$.

Niekiedy znoszone granice polityczne pozostają formami barier przestrzennych, które kształtują środowisko lokalnych społeczności i niejako „konserwują” odmienność kulturową regionów. Takim materialnym elementem krajobrazu w wymiarze przyrodniczym, znaczącym linię granicy między Galicją a Królestwem Polskim, jest przebieg rzeki San między Kopkami a Krzeszowem (ryc. 3). Wprawdzie poza starymi mapami fakt ten nie jest formalnie odnotowany, a mieszkańcy mogą bez przeszkód przemieszczać się mostem spinającym dwa brzegi rzeki, jednak w pamięci społecznej i w praktykach symbolicznego oznaczania przestrzeni ten liminalny wymiar cieku może zostać odnotowany przez badacza. Zdarza się, że specyfikę krajobrazu kulturowego sprzed 1918 r. dokumentują zachowane jeszcze z tamtego okresu pierzeje ulic czy fragmenty zabudowy (ryc. 5). Innym razem pamięć krajobrazu wyraża się w drobnych, lecz wymownych elementach, takich jak chociażby fragment słupa granicznego w Radomyślu, wkopany na początku listopada 1918 r., po uroczystości znoszącej granice rozbiorowe (ryc. 4). Jeszcze inne przykłady pokazują, że lokalna tożsamość związana z rzeczywistością końca XIX i początku XX w. jest tak silna, iż w przypadku utracenia pewnych elementów materialnych tworzone są ich rekonstrukcje (ryc. 5). Dzięki nim pamięć społeczna jest wciąż żywa i wytwarza specyfikę obszarów rozciągających się wzdłuż dawnych granic rozbiorowych.

Wiele z tych elementów ulega stopniowej degradacji lub jest nieczytelne dla współczesnego odbiorcy. Często owo dziedzictwo kulturowe jest niedocenionym aspektem krajobrazu, gdy tymczasem stanowi o jego unikatowości. Obecność elementów nawiązujących do dawnych podziałów politycznych może być szansą dla promowania i rozwijania terenów dawnego pogranicza, które współcześnie pełnią funkcję „zakrytych” krajobrazów pamięci. Wykorzystanie dziedzictwa kulturowego jako inspiracji do odpowiedzialnego budowania i podkreślania współczesnej tożsamości tych terenów ${ }^{91}$

89 M. Sobczyński, Trwatość dawnych granic państwowych w krajobrazie kulturowym Polski, Warszawa 1993, s. 7. T. Padło, Wptyw granicy rozbiorowej na zróżnicowanie zachowań i świadomości mieszkańców pótnocnej czę́si województwa matopolskiego, praca magisterska, maszynopis, Kraków 2003. T. Supernat, Trwatość dawnej granicy politycznej polsko-niemieckiej w obecnym krajobrazie kulturowym i w świadomości ludności na przyktadzie gmin: Eubnice, Byczyna Kluczborska, Perzów i Dziadowa Ktoda, praca magisterska, maszynopis, Łódź 1989.

M. Sobczyński, Trwatość dawnych granic..., s. 7.

91 S. McDowell, Heritage, Memory and Identity, „The Ashgate Research Companion to Heritage and Identity", s. 37-53; [online] http://www.campusincamps.ps/wp-content/uploads/2015/11/ McDowell-Heritage-08.pdf, 5 III 2018. 
może mieć kluczowe znaczenie dla ich przyszłego funkcjonowania i przyczynić się do aktywnej ochrony zachowanych śladów dawnych granic rozbiorowych Polski.

Ryc. 3. Rzeka San między Kopkami a Krzeszowem - dawna granica między Galicją a Królestwem Polskim

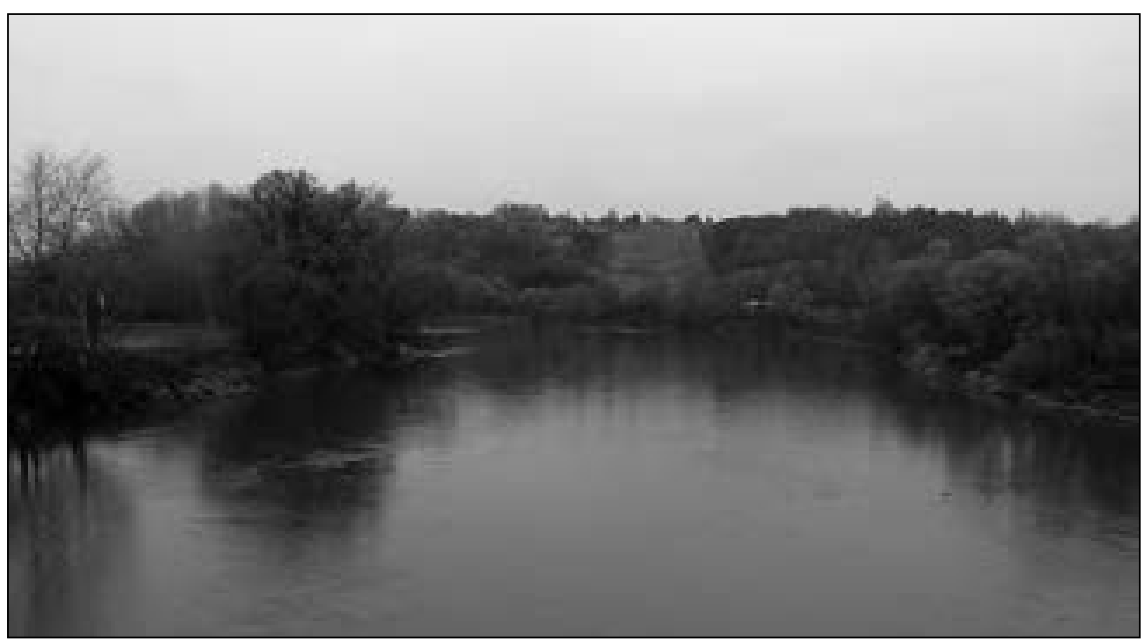

Źródło: fot. D. Porczyński 2018

Ryc. 4. Radomyśl nad Sanem - fragment słupa granicznego wkopanego na początku listopada 1918 r.

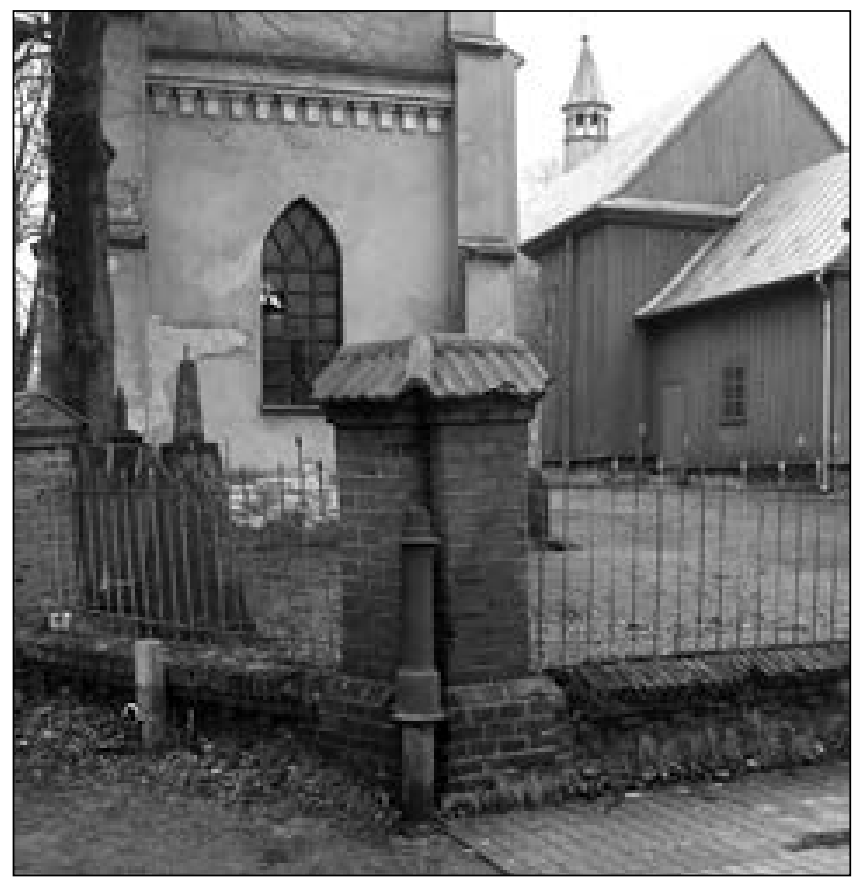

Źródło: fot. D. Porczyński 2018 
Ryc. 5. Oryginalna małomiasteczkowa zabudowa Radomyśla nad Sanem z początku XX w.

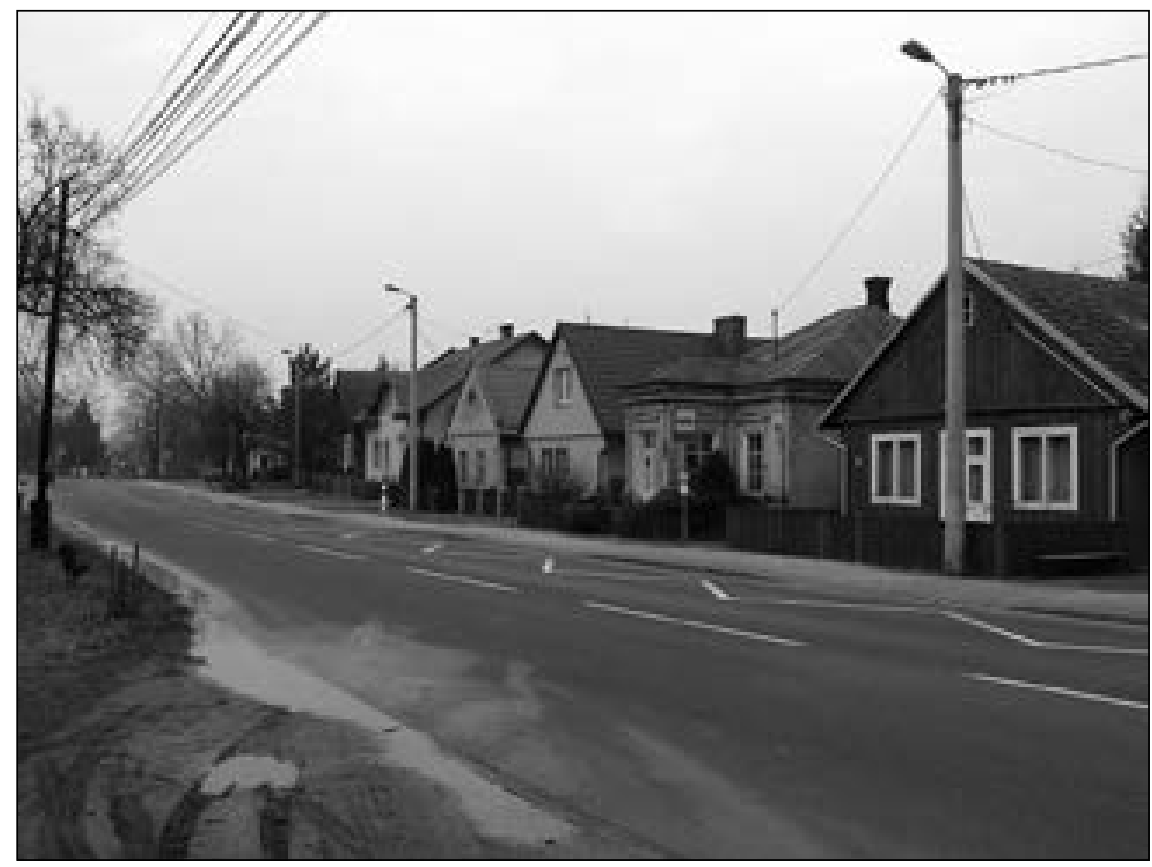

Źródło: fot. D. Porczyński 2018

Ryc. 6. Łążek - teren przebiegu dawnej granicy między Galicją a Królestwem Polskim. Widoczna kaplica znajduje się na miejscu cerkwi stanowiącej część kompleksu koszar carskiej straży granicznej

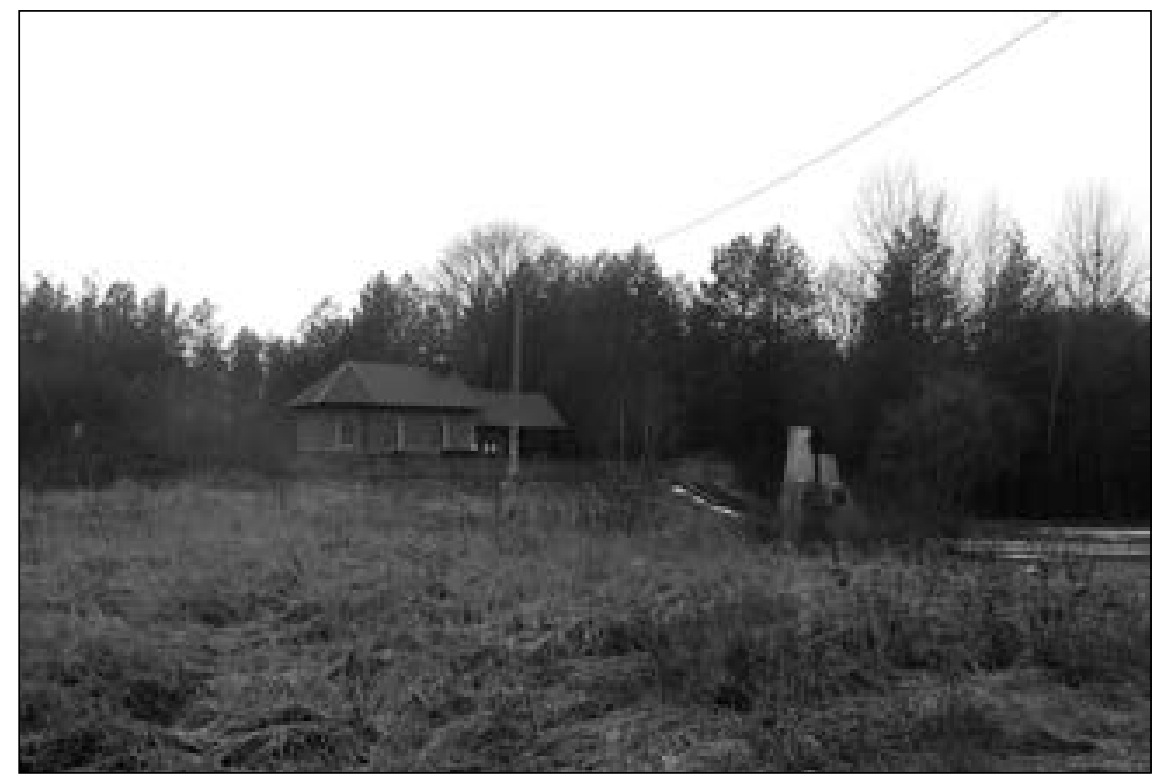

Źródło: fot. D. Porczyński 2018 
Ryc. 7. Dąbrowa Rzeczycka - odtworzone przejście graniczne (implant pamięci)

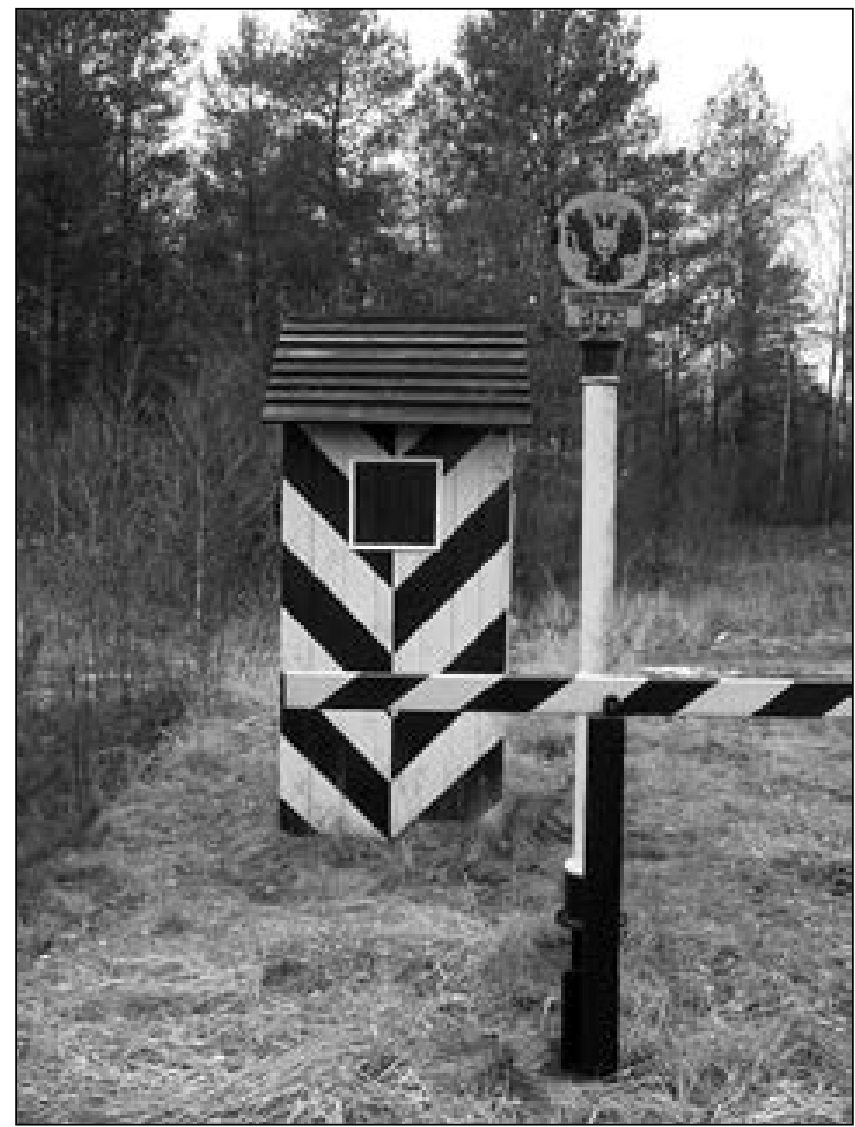

Źródło: fot. D. Porczyński 2018

\section{PODSUMOWANIE}

Nakładając na siebie różne perspektywy badania granic: socjologiczną, antropologiczną, muzeologiczną i krajobrazową, podjęliśmy próbę znalezienia wspólnego dla nich elementu, pozwalającego zintegrować różnorodność danych i procedur badawczych. Tym integrującym zjawiskiem jest materialność, będąca wytworem i korelatem funkcjonowania jednostek i społeczności, przejawiająca się w obiektach fizycznych, wytworach ludzkich różnego typu i różnej skali, ale również w krajobrazie: tym zachowującym przewagę elementów naturalnych, a także przekształconym, poprzecinanym rowami i urozmaiconym pozostałościami komór celnych lub implantami pamięci w postaci rekonstrukcji przejść granicznych. Na tę wizualną i namacalną rzeczywistość nakłada się rzeczywistość symboliczna, niemożliwa do zarejestrowania inaczej niż poprzez dotarcie do sfery psychologicznej w toku badań etnograficznych, które mają długotrwałą 
tradycję integrowania rozmaitych technik badawczych w celu uzyskania szczegółowego obrazu eksplorowanej społeczności. Oczywiście specyfika współczesnych, „usieciowionych" kultur lokalnych wydaje się kontrastowo różna od tych funkcjonujących jeszcze w czasach rozbiorów, ale i te przemiany wychwytują antropologowie, decydując się nie tylko na pozostawanie w jednym punkcie, lecz również prowadzenie symultanicznych lub sukcesywnych wycinków badań, nie rezygnując z podążania za mobilnym nieraz ich przedmiotem ${ }^{92}$.

Dziedzictwo granic rozbiorowych funkcjonuje w ramach tak projektowanego badania na co najmniej trzy sposoby. Po pierwsze, może być nośnikiem wiedzy, świadectwem przeszłości. Jednak poprzestawanie na budowaniu obrazu przeszłości wyłącznie na podstawie dostępnych danych zastanych nie powie wiele na temat współczesnego ich funkcjonowania. Po drugie zatem, pojawiają się obiekty występujące jako kontekst i składniki praktyk codziennych, odświętnych, zakorzenionych głęboko w tożsamości lub wynikających ze specyfiki przestrzeni fizycznej pogranicza fantomowego. Po trzecie wreszcie, przedmioty wykorzystywane przez badacza mogą być dla uczestnika badań katalizatorem jego refleksji na temat rzeczywistości, w której funkcjonuje. W tej sytuacji można je potraktować na dwa sposoby. W pierwszym przypadku jako punkt wyjścia do badania obok standardowo wykorzystywanej listy poszukiwanych informacji zawartych w scenariuszu, jako bodziec wywołujący narrację informatora. W tym aspekcie badania krajobrazowe i kwerendy muzealne należałoby potraktować jako pierwszy etap badania etnograficznego, pozwalający sporządzić katalog miejsc i przedmiotów ewokujących granicę fantomową. Rozpoczynając eksplorację nowego terenu, nie zawsze jednak wiadomo, „gdzie patrzeć” i który element w przestrzeni jest faktycznie istotny dla ustalenia tożsamości pogranicznych. Drugą możliwością jest rozpoczęcie badań od odnoszenia się do praktyk i pamięci, co oznacza, że w toku intensywnych wywiadów można sporządzić listę miejsc i przedmiotów znaczących (bo wspominanych) dla społeczności. W tym przypadku jednak nie ma pewności, że w sztucznej skądinąd sytuacji rozmowy informator nie pominie (celowo lub przypadkowo) ważnego fragmentu układanki, zubażając generowaną teorię. Wydaje się zatem, że najbardziej obiecującą perspektywą jest zastosowanie obu podejść, które w ten sposób będą się wzmacniać. Należy potraktować przedmioty oraz elementy krajobrazu jako węzły tworzące sieć pamięci (lub niepamięci), spinające lub generujące poszczególne połączenia między przedmiotami, symbolami i praktykami. Procesy eksploracji terenu, muzeum i wywiadów powinny się nakładać, a zatem być prowadzone symultanicznie, ale też cyklicznie - poprzez wielokrotne powtarzanie badania krajobrazu, spacerów badawczych, badań wizualnych i wywiadów, poprzez stałe odnoszenie się do danych generowanych z wykorzystaniem różnych technik. Dlatego właśnie metoda etnograficzna wydaje się najwartościowszą ramą dla omawianych praktyk.

92 J. Clifford, Praktyki przestrzenne: badania terenowe, podróże i praktyki dyscyplinujące $w$ antropologii, [w:] Badanie kultury. Elementy teorii antropologicznej. Kontynuacje, przet. S. Sikora, red. M. Kempny, E. Nowicka, Warszawa 2006, s. 139-179. G.E. Marcus, Ethnography In/Of The World System: The Emergence of Multi-Sited Ethnography, „Annual Reviews of Anthropology” 1995, vol. 24, s. 95-117. 
Jak wykazaliśmy, granica stanowi konstrukcję zarówno symboliczną, jak i materialną oraz - w czym zgadzamy się z Chiarą Brambillą ${ }^{93}$ - stanowi rezultat przeplatania się wielości dyskursów, praktyk i relacji. Składają się na nią procesy geopolityczne, ale też codzienne praktyki społeczne, stąd należy je rozpatrywać zarówno w ujęciu materialnym, jak też procesualnym. Wpisuje się to w perspektywę "granicobrazowania” (borderscaping), której szczególna doniosłość przejawia się m.in. w tym, że podkreśla trwanie granic nawet po ich formalnym zniesieniu, uwzględnia wielość punktów widzenia i wielopłaszczyznowość ich funkcjonowania, relacje między różnego rodzaju przejawami aktywności społecznej, ale też jej wytworami ${ }^{94}$. Badanie relacji między tożsamością, światem przedmiotów i krajobrazem obszarów rozciągających się wokół dawnych granic Galicji i Królestwa Polskiego, zintegrowane w metodzie etnograficznej, wspomaganej nowoczesnymi technologiami (mapami satelitarnymi i LIDAR) oraz analizami statystycznymi, włącza się zatem w podejmowaną przez innych badaczy dyskusję i sprzyjać może generowaniu danych o znacznej doniosłości poznawczej.

\section{BIBLIOGRAFIA}

Anderson B., Wspólnoty wyobrażone. Rozważania o źródtach i rozprzestrzenianiu się nacjonali$z m u$, przel. S. Amsterdamski, Warszawa 1997.

Ashworth G., Planowanie dziedzictwa, przeł. M. Duda-Gryc, Kraków 2015.

A. Assmann, Kreowanie obrazu przesztości w muzeach, [w:] taż, Między historia a pamięcią. Antologia, przeł. P. Pieńkowska-Wiederkehr, red. nauk. i posł. M. Saryusz-Wolska, Warszawa 2013, s. 253-254.

Bal M., The Discourse of the Museum, [w:] Thinking About Exbibitions, red. R. Greenberg, B.W. Ferguson, S. Nairne, London-New York 1996.

Barth F., Boundaries and Connections, [w:] Signifying Identities. Anthropological Perspectives on Boundaries and Contested Values, London 2000.

Bartkowski J., Tradycja i polityka. Wptyw tradycji kulturowych polskich regionów na wspótczesne zachowania spoteczne i polityczne, Warszawa 2003.

Bartkowski J., Tradycja zaborów a wspótczesne zachowania spoteczne w Polsce, [w:] Oblicza lokalności. Tradycja i wspótczesność, red. J. Kurczewska, Warszawa 2004.

Bauman Z., Spoteczeństwo w stanie oblężenia, przeł. J. Margański, Warszawa 2006.

Bogdanowski J., Krajobraz zabytkowy jako wyraz tożsamości, „Teka Komisji Urbanistyki i Architektury" 1976, vol. 10.

Borejza T., Mit Galicji, „Przegląd” 2015, vol. 792, nr 10.

Brambilla C., Exploring the Critical Potential of the Borderscapes Concepts, „Geopolitics” 2014, vol. 20, nr 1 .

93 C. Brambilla, Exploring the Critical Potential of the Borderscapes Concepts, „Geopolitics” 2014, vol. 20, nr 1, s. 22.

94 C. Brambilla et al., Introduction: Thinking, Mapping, Acting and Living Borders Under Contemporary Globalisation, [w:] Borderscaping: Imaginations and Practices of Border Making, red. C. Brambilla et al., New York 2016, s. 1-2. 
Brambilla C. et al., Introduction: Thinking, Mapping, Acting and Living Borders Under Contemporary Globalisation, [w:] Borderscaping: Imaginations and Practices of Border Making, red. C. Brambilla et al., New York 2016.

Bruzda J., Kultura miejsca, „Teka Komisji Urbanistyki i Architektury” 1996, vol. 28.

Byczkowska D., Ciato w tańcu. Analiza socjologiczna, Łódź 2012.

Charmaz K., Teoria ugruntowana. Praktyczny przewodnik po analizie jakościowej, przeł. B. Komorowska, Warszawa 2009.

Chłopecki J., Czas, świadomość, historia, Warszawa 1989.

Clifford J., Ktopoty z kulturą. Dwudziestowieczna etnografia, literatura i sztuka, przeł. E. Dżurak $\mathrm{i}$ in., Warszawa 2000.

Clifford J., Praktyki przestrzenne: badania terenowe, podróże i praktyki dyscyplinujace w antropologii, [w:] Badanie kultury. Elementy teorii antropologicznej. Kontynuacje, tłum. S. Sikora, red. M. Kempny, E. Nowicka, Warszawa 2006.

Cohen A., Symbolic Construction of Community, London 1985.

Dobrowolski K., Teoria podtoża historycznego, [w:] Studia z pogranicza historii i socjologii, red. K. Dobrowolski, Wrocław 1967.

Durkheim E., The Division of Labour in Society, London 1994.

Gajdek A., Cieśla B., Relikty uktadów ruralistycznych w strukturze wspótczesnego miasta. Zachowane dziedzictwo w kontekście zatożeń miasta przysztości, na przyktadzie Rzeszowa, „Journal of Civil Engineering, Environment and Architecture" 2017, vol. 34, nr 64.

Geertz C., Interpretacja kultur. Wybrane eseje, przeł. M.M. Piechaczek, Kraków 2005.

Geertz C., Wiedza lokalna. Dalsze eseje z zakresu antropologii interpretatywnej, przeł. D. Wolska, Kraków 2005.

Gell A., Art and Agency, Oxford 1998.

Giulianotti R., Robertson R., Forms of Glocalization: Globalization and the Migration Strategies of Scottish Football Fans in North America, „Sociology” 2007, vol. 41.

Golka M., Pamięć spoteczna i jej implanty, Warszawa 2009.

Gupta A., Ferguson J., Discipline and Practice: "the field" as site, method, and location in anthropology, [w:] Anthropological Locations, Boundaries And Grounds of a Field Science, red. A. Gupta, J. Ferguson, Berkeley 1997.

Halbwachs M., On Collective Memory, Chicago 1992.

Hirschausen B. von, et al., Phantomgrenzen: Räume und Akteure in der Zeit neu denken, Göttingen 2015.

Hobsbawm E., Introduction: Inventing Tradition, [w:] The Invention of Tradition, red. E. Hobsbawm, T. Ranger, Cambridge 2000.

Jałowiecki B., Spoteczne wytwarzanie przestrzeni, Warszawa 2010.

Jańczak J., Phantom Borders and Electoral Behaviour in Poland. Historical Legacies, Political Culture and Their Influence on Contemporary Politics, „Erdkunde” 2015, vol. 69, nr 2, https:// www.doi.org/10.3112/erdkunde.2015.02.02.

Jordanova L., Objects of Knowledge: A Historical Perspective on Museums, [w:] The New Museology, red. P. Vergo, London 1989.

Kempny M., Kultura lokalna w świecie kulturowych hybryd, „Kultura Współczesna” 2004, nr 4.

Konecki K., Wizualna teoria ugruntowana. Podstawowe zasady i procedury, „Przegląd Socjologii 
Jakościowej" 2012, nr 1, [online] http://www.qualitativesociologyreview.org/PL/Volume18/PSJ_8_1_Konecki.pdf.

Koseła R., Sandomierskie strony, Warszawa 1939.

Krajewski M., Są w życiu rzeczy... Szkice z socjologii przedmiotów, Warszawa 2013.

Krzywicki L., Rozwój spoteczny wśród zwierząt i u rodzaju ludzkiego, „Świat i Człowiek” 1913, nr 4.

Kurczewska J., Dwie ideologie lokalności z narodem w tle, „Kultura i Społeczeństwo” 2003, nr 3.

Kurczewska J., Kreacje matych ojczyzn, „Societas/Communitas” 2015, vol. 1-2.

Kurczewska J., Robocze ideologie lokalności. Stare i nowe schematy, [w:] Oblicza lokalności. Tradycja i wspótczesność, red. J. Kurczewska, Warszawa 2004.

Latour B., Reassembling the Social. An Introduction to Actor-Network Theory, New York 2005.

Levitt P., Artifacts and Allegiances. How Museum Put the Nation and the World on Display, Oakland 2015.

Löwis S. von, Phantom borders in the political geography of East Central Europe: an introduction, „Erdkunde” 2015, vol. 69, no. 2, https://www.doi.org/10.3112/erdkunde.2015.02.01.

McDowell S., Heritage, Memory and Identity, The Ashgate Research Companion to Heritage and Identity, [online] http://www.campusincamps.ps/wp-content/uploads/2015/11/ McDowell-Heritage-08.pdf, 5 III 2018.

Marcus G.E., Ethnography in/of the World System: the Emergence of Multi-Sited Ethnography, „Annual Review of Anthropology” 1995, vol. 24.

Mickiewicz A., Pan Tadeusz, Warszawa 2017.

Myczkowski Z., Krajobraz wyrazem tożsamości w wybranych obszarach chronionych $w$ Polsce, Kraków 2003.

Myga-Piątek U., Krajobrazy kulturowe. Aspekty ewolucyjne i typologiczne, Katowice 2012.

Myszka S., Radomyśl nad Sanem. Dzieje miasta i parafii, Stalowa Wola 2004.

Nowak J., Spoteczne reguty pamiętania. Antropologia pamięci zbiorowej, Kraków 2011.

Nowak S., Metodologia badań spotecznych, Warszawa 2010.

Ossowski S., O ojczyźnie i narodzie, Warszawa 1986.

Padło T., Wptyw granicy rozbiorowej na zróżnicowanie zachowań i świadomości mieszkańców pótnocnej części województwa matopolskiego, praca magisterska, maszynopis, Kraków 2003.

Pomian K., Collectors and Curiosities. Paris and Venice 1500-1800, Cambridge 1990.

Pomian K., Historia. Nauka wobec pamięci, Lublin 2006.

Porczyński D., Muzea podkarpackie 2004-2014. Globalizacja i europeizacja a przeobrażenia lokalnych instytucji kultury, Rzeszów 2016.

Porczyński D., Realne i wirtualne kręgi spoteczne. Socjologiczna analiza użytkowników gier fabularnych, Rzeszów 2014. Maszynopis pracy doktorskiej.

Porczyński D., Rola muzeów w budowie konkurencyjności samorządów lokalnych województwa podkarpackiego, „UR Journal of Humanities and Social Sciences” 2017, vol. 4, nr 3, https:// www.doi.org/10.15584/johass.2017.3.4.

Sacha M., Fantomowe dziedzictwo? Różnice w muzealnej prezentacji dziedzictwa niemieckiego wschodu oraz polskich Kresów - próba diagnozy, „Rocznik Antropologii Historii” 2016, vol. 9. 
Sacha M., Z biegiem Piaśnicy. Miejsca pamięci wokót "granicy fantomowej" na Pótnocnych Kaszubach, „Przegląd Zachodni” 2015, nr 3.

Simmel G., Bridge and Door, „Theory Culture Society” 1994, vol. 11.

Simmel G., Obcy, [w:] tegoż, Most i drzwi, przeł. M. Łukasiewicz, Warszawa 2006.

Šimon M., Measuring Phantom Borders: The Case of Czech/Czechoslovakian Electoral Geography, „Erdkunde” 2015, vol. 69, nr 2, https://www.doi.org/10.3112/erdkunde.2015.02.04.

Smith C.S., Museums, Artefacts, and Meanings, [w:] The New Museology, red. P. Vergo, London 1989.

Sobczyński M., Trwatość dawnych granic państwowych w krajobrazie kulturowym Polski, Warszawa 1993.

Supernat T., Trwatość dawnej granicy politycznej polsko-niemieckiej w obecnym krajobrazie kulturowym i w świadomości ludności na przyktadzie gmin: Eubnice, Byczyna Kluczborska, Perzów i Dziadowa Ktoda, praca magisterska, maszynopis, Łódź 1989.

Surowaniec Z., Na granicy gmin powstata rekonstrukcja przejścia granicznego z okresu rozbiorów, „Echo Dnia”, [online] http://www.echodnia.eu/podkarpackie/wiadomosci/stalowa-wola/ art/8480478,na-granicy-gmin-powstala-rekonstrukcja-przejscia-granicznego-z-okresu-zaborow,id,t.html, 2 III 2018.

Szacka B., Czas przeszty, pamięć, mit, Warszawa 2006.

Taine H., Filozofia sztuki, przeł. A. Sygietyński, Warszawa 1896.

Tomaszewski A., Ku nowej filozofii dziedzictwa, Kraków 2012.

Tönnies F., Community and Civil Society, Cambridge 2001.

Wallerstein I., Time and Duration: The Unexcluded Middle, or Reflections on Braudel and Prigogine, „Thesis Eleven” 1998, vol. 54.

Wallerstein I., World-System Analysis. An Introduction, Durham 2006.

Weil S.E., Rethinking the Museum: An Emerging New Paradigm, [w:] Reinventing the Museum, red. G. Anderson, Lanham 2004.

Wierzejska J., Idea Galicji po(st)granicznej w ukraińskim i polskim dyskursie postkolonialnym. Na przyktadzie eseistyki Jurija Andruchowycza i Andrzeja Stasiuka, „Teksty Drugie” 2014, nr 6.

Wojakowski D., Kultura lokalna, czyli węzet symboliczny, [w:] Oblicza lokalności. Różnorodność miejsc i czasu, red. J. Kurczewska, Warszawa 2006.

Wojakowski D., O technice malowania obrazów, czyli teoretyczne dylematy socjologii pogranicza, „Przegląd Polonijny” 2002, vol. 29, nr 3.

Wojakowski D., Polacy i Ukraincy. Rzecz o pluralizmie i tożsamości na pograniczu, Kraków 2002.

Ustawa z dn. 23 lipca 2003 o ochronie zabytków i opiece nad zabytkami, Dz. U. 2003 nr 162 poz. 1568 , s. 2.

Zachariasz A., Krajobrazy pamięci wyrazem tożsamości miejsca, „Prace Komisji Krajobrazu Kulturowego" 2011, vol. 15, [online] http://krajobraz.kulturowy.us.edu.pl/publikacje.artykuly/niematerialne/zachariasz.pdf, 7 III 2018.

Znaniecki F., Grupy spoteczne jako wytwory uczestniczacych w nich jednostek, [w:] J. Szacki, Znaniecki, Warszawa 1986.

Znaniecki F., Metoda socjologii, przeł. i wstęp E. Hałas, Warszawa 2008. 
Znaniecki F., Relacje spoteczne i role spoteczne. Niedokończona socjologia systematyczna, przeł. i przedm. E. Hałas, Warszawa 2011.

Znaniecki F., The Social Role of the University Student, Poznań 1997.

Znaniecki F., Wspótczesne narody, przeł. Z. Dulczewski, wstęp J. Szacki, Warszawa 1990.

Dr inż. arch. kraj. Agata GAJDEK - adiunkt w Zakładzie Architektury Krajobrazu na Wydziale Biologiczno-Rolniczym Uniwersytetu Rzeszowskiego. Prezes podkarpackiego oddziału Stowarzyszenia Polskich Architektów Krajobrazu. Jej dotychczasowa działalność naukowa związana jest z miejskimi przestrzeniami rekreacji, tradycyjną architekturą drewnianą oraz problematyką poszukiwania i definiowania lokalnej tożsamości krajobrazu kulturowego.

Dr Dominik PORCZYŃSKI - adiunkt w Instytucie Socjologii Uniwersytetu Rzeszowskiego. Członek zarządu Polskiego Towarzystwa Kulturoznawczego. Autor i redaktor prac z zakresu muzeologii, kulturoznawstwa, teorii socjologicznej, socjologii sztuki i socjologii nowych mediów, m.in. Muzea podkarpackie 2004-2014. Globalizacja i europeizacja a przeobrażenia lokalnych instytucji kultury (red. wraz z T. Kośkiem 2016), Krag spoteczny: od klasycznej metafory do wspótczesnych uję́ analitycznych, „Przegląd Humanistyczny" (2017). 